\title{
The Systemic Approach for Estimating and Strategizing Energy Security: The Case of Ukraine
}

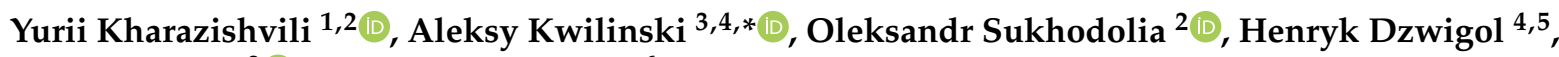 \\ Dmytro Bobro $^{2}$ and Janusz Kotowicz ${ }^{6}$
}

1 Department of Regulatory Policy and Entrepreneurship Development, Institute of Industrial Economics of the National Academy of Sciences of Ukraine, 2 Maria Kapnist St., 03057 Kyiv, Ukraine; yuri_mh@ukr.net

2 National Institute for Strategic Studies, 7-A Pyrohova St., 01054 Kyiv, Ukraine; sukhodolia@gmail.com (O.S.); dgbobro@gmail.com (D.B.)

3 The London Academy of Science and Business, 120 Baker St., London W1U 6TU, UK

4 Department of Marketing, Sumy State University, 2 Rymskogo St., 40007 Sumy, Ukraine; henryk.dzwigol@poczta.fm

5 Department of Management and Logistics, Faculty of Organization and Management, Silesian University of Technology, 26-28 Roosevelt St., 41-800 Zabrze, Poland

6 Department of Power Engineering and Turbomachinery, Silesian University of Technology, 18 Konarskiego St., 44-100 Gliwice, Poland; janusz.kotowicz@polsl.pl

* Correspondence: a.kwilinski@london-asb.co.uk

check for updates

Citation: Kharazishvili, Y.; Kwilinski, A.; Sukhodolia, O.; Dzwigol, H.; Bobro, D.; Kotowicz, J. The Systemic Approach for Estimating and Strategizing Energy Security: The Case of Ukraine. Energies 2021, 14, 2126. https://doi.org/10.3390/ en14082126

Academic Editor:

Manuela Tvaronavičienè

Received: 26 March 2021

Accepted: 5 April 2021

Published: 10 April 2021

Publisher's Note: MDPI stays neutral with regard to jurisdictional claims in published maps and institutional affiliations.

Copyright: (c) 2021 by the authors. Licensee MDPI, Basel, Switzerland. This article is an open access article distributed under the terms and conditions of the Creative Commons Attribution (CC BY) license (https:/ / creativecommons.org/licenses/by/ $4.0 /)$.

\begin{abstract}
The current approaches to estimating the level of energy security are based on applying a comprehensive approach to selecting the factors that affect energy security and the dynamics of processes in this domain. This article reveals the application of the model of energy security estimation and strategizing based on the systemic description of energy security as an object of management: the integral system, elements and connections, functions, processes, and the system's material. At the same time, this model is able to take into account the dynamics of technological, political, economic, and other factors operating in the country and on the global arena. The energy security estimation model developed uses a modern methodology of integrated estimation: a multiplicative form of the integrated index, a formalized definition of the safe existence limits in order to provide scientific substantiation of the threshold vector, a modified rationing method, the principal components method, and the sliding matrix method to substantiate dynamic weighting coefficients. The paper demonstrates the systemic approach application to shaping strategic goals in the energy security domain in the context of sustainable development; the trajectory of energy security development is calculated by the method of strategizing that applies the principle "future is determined by the trajectory to the future" instead of the classical forecasting "past determines the future". In general, the article shows the possibility of unifying the process of formalizing energy security (according to the needs of the researcher: country, industry, energy network, supply chain) as an object of management, estimating energy security status, and strategizing the regulatory sphere transformation in accordance with the target values for monitoring the effectiveness of management.
\end{abstract}

Keywords: energy security; strategic planning; system approach; evaluation; sustainable development; integral index

\section{Introduction}

Estimating the level of the country's energy security is a rather difficult task, which is due to the specificity of describing the energy security domain, public administration and corporate management models and patterns, approaches to formalization, and methods of estimating the state (level) of energy security and threats.

The complexity of the energy security description lies in the fact that describing this object requires consideration of various aspects of the country's life. Currently, there is no single methodological approach to shaping the energy security domain. The vast 
majority of research estimating the state of energy security is carried out by using an integrated approach.

Typically, an object is described through a set of parameters that characterize its main properties and distinctions. Sets are grouped based on the criterion of similarity in the selected trait. In this way, there are most often groups of obtained indicators, such as economic, political, technological, environmental, social, managerial, etc. [1-24]. The problem of applying an integrated approach is a fairly arbitrary choice of groups of parameters that the researcher believes are important for analysis. The importance of these parameters is determined by the researcher in terms of their current knowledge and technological development, political preferences, and security situation.

In order to avoid selecting the parameters erroneously, the researcher generalizes other scholars' findings in this field in the attempt to identify the most significant ones. However, this method does not allow validating the sets of parameters which could be applied to various countries or to various stages of socio-economic, political, or technological development of the same country in order to estimate their state of energy security.

This approach over time leads to a constant expansion of the set of "important" parameters. Thus, based on researchers' analyses [1,2,4-17], energy security should be determined by the influence of factors that they grouped into four groups: the availability of energy, its affordability, efficiency of its use, and environmental stewardship. A. Azuni and C. Breyer [3], analyzing the research for the period of 1971-2016, distinguish between 15 groups of parameters (availability, diversification, price, technology and efficiency, localization, time interval, sustainability, environment, health, culture, access to information, employment, public policy, military dimension, and cybersecurity) [18], which are necessary to describe the object of energy security management. At the same time, the set of parameters for energy security analysis argued in this way does not allow for its application to the specific conditions of each country.

Therefore, in our opinion, the application of an integrated approach does not allow for developing a universal method of selecting the parameters of energy security estimation for different countries and the specific conditions of their energy markets. Moreover, the application of such an approach does not allow for energy security strategizing, as changes in selecting parameters due to technological changes or changes in energy market patterns actually necessitate a revision of the methodology for estimating energy security, selecting new estimation indicators, and searching for new data for calculations.

In our opinion, it is this circumstance that becomes the reason why most research focuses on the development of energy security estimation and does not pay attention to the problem of strategizing.

The constant expansion of the set of parameters for estimating energy security stipulates the existence of another trend in the subject of research, namely the narrowing of the scope of attention, limiting the subject of study to individual subsystems, reducing and fixing a separate set of parameters to be taken into account.

In countries with a high level of market economy maturity, the object of study (energy security domain) is restricted to the economic regulation of the processes of the physical availability of primary energy resources, the reliability of technological equipment, and the efficiency of economic models of energy markets. It is this understanding that is reflected in many definitions of the term "energy security".

The International Energy Agency (IEA) emphasizes that energy sources should be continually available and affordable [19], specially highlighting such individual parameters as physical availability of resources, their uninterrupted supply and economic affordability.

A kind of extension of this approach is proposed in the study by the Asia Pacific Energy Research Center (APERC) [18]. It proposed singling out four aspects that should be studied in terms of their impact on energy security, namely: resource adequacy, technical reliability, economic profitability, and environmental acceptability. In fact, the scope of the energy security analysis adopted by the IEA was expanded to include the environmental component, which has become increasingly important in energy markets and energy secu- 
rity policy. The " 4 A's" approach (availability, accessibility, affordability, and acceptability) has gained widespread popularity among researchers, and has become a kind of a pattern to form a set of four groups of parameters for energy security analysis.

At the same time, such a definition of the boundary of the object of management is quite specific, and suitable mainly for use in countries with an established pattern of democratic governance, a mature market economy, and only in a stable situation within energy markets. In our opinion, this approach, although logical, does not take into account the impact of political decisions on the functioning of energy markets, which do not always correspond to economic logic.

Another approach to limiting the set of parameters that must be taken into account when analyzing the impact on energy security is C. Winzer's approach. Based on the results of his own analysis of existing approaches, he proposes considering only the process of ensuring the stability of energy supply, thus narrowing the interpretation of energy security to "continuity of energy supply according to needs" [17]. The remaining aspects (for example, economic, environmental, or social components) were proposed to be classified as threats and, accordingly, to operate them in the logic of risk management, identifying sources of risk (technical, human, natural threats), and the level of their predictability (predictable, plausible, hardly predictable, and unknown).

The stance of the authors $[5,20,21]$ coincides with the logic of narrowing the subject of analysis in the field of energy security. They propose to simplify the analysis of energy security by assessing threats and ensuring the security of "vital energy systems", as it is these systems that are united by one process of "energy flow" (energy resources, technologies, and consumers) and provide critical functions of a society/country. This approach of the authors is reflected in the methodology of the energy security estimation of the International Energy Agency [19].

At the same time, the tendency towards narrowing the scope of attention or the subject of regulation in the field of energy security cannot be considered justified for countries with economies in transition [7,10,22]. In countries with economies in transition, decisions on energy market patterns, development priorities of state-owned energy companies (which usually occupy a significant part of the market), and principles of ensuring energy security are made based on the priority of ensuring electoral sympathies. Often, the energy policies of such countries are based on the logic of populism, and are aimed both at achieving short-term political goals and at providing opportunities for the "rent exploitation" of the energy industry by pro-government influence groups. As a result, entire fuel and energy sectors and state-owned companies become a source of support for "state social paternalism", forcing state-owned companies to operate at a loss.

This aspect is not considered at all by scholars from established democracies and market economies, and theoretical and political concepts of energy security in Western countries do not even contain a conceptual idea of the possibility of political decision making by the country's government that directly affects the country's energy security. At the same time, this creates a demand for taking into account the domestic policy impact on the level of the country's energy security [22].

At the same time, energy security is involved in ensuring the country's sovereignty and independence. This aspect has become especially relevant for Ukraine since 2014. Influence on the country's energy policy, obstruction of energy supply systems, and, as a consequence, violation of sustainable living conditions of the population has become one of the most important tools of hybrid aggression against Ukraine [23].

Therefore, there emerges the task of balancing the objective variability of the required set of parameters for the adequate estimation of energy security in accordance with changes in the external environment (technological and economic development, changing geopolitical and climatic conditions, specific features of the country's fuel and energy sector, etc.) with the need for a sustainable methodological approach to their selection based on the practical needs of the researcher (country, industry, etc.). 
The use of a systemic approach to highlighting the scope and subject of the research (object of management) is such a methodological approach to the unification of estimating and strategizing processes in the field of energy security. The description of the object of management in the form of a "system" requires researchers to identify the components of the system (or groups of parameters), namely the selection of "elements", "connections", "structure", "functions", "processes", and "materials". This requirement allows for unifying the process of determining the parameters of describing energy security for any object (countries, industries, supply systems, etc.), their functioning, and the dynamics of various factors of influence [24]. The application of a systemic approach allows differentiating and removing the existing discussion on the interpretation of energy security as a "status" or "capability" of the system.

Regarding methodological approaches to assessing the level of energy security, it is possible to distinguish the works [1-4,10-13,25-28]. Study [1] evaluates Pakistan's energy security indicators based on a study of its energy security index in the period of 1991-2018, which focuses on the concepts of "Accessibility", "Affordability”, "Technology", "Management", and "Environment". Study [2] aims to evaluate the energy security status using sets of indicators, indices, and structures, taking into account their dependence on different fuels, their general economic situation, energy pricing policy, access to renewable energy sources, and international relations. The research from [3] notes the lack of a comprehensive definition that takes into account all aspects of energy security, as well as the lack of well-studied relations between energy security and its dimensions. In paper [4], energy policy and practice are correlated with the multidimensional concept of energy security and empirical results for forty years. The research in [25] is devoted to examining the energy security performance indicators in 30 Chinese provinces from 2008-2017 by proposing a hybrid model that combines a fuzzy best-worst method, data coverage analysis, and warranty regions. In the work of [26], it is assumed that energy security contains valuable information that can predict the profitability of energy reserves. The research in [27] presents the World Energy Council's Energy Trilemma Index, developed in partnership with Oliver Wyman, and ranks countries by their ability to provide sustainable energy on three parameters: energy security, energy justice (accessibility and affordability), and environmental sustainability. The research from [28] calculates the International Energy Security Risk Index, the first energy risk indicator of its kind, which uses quantifiable data, information on historical trends, and government forecasts to determine policies and other factors that positively or negatively affect international energy security.

Thus, the purpose of this article is to scientifically substantiate strategic scenarios of the future security situation of the energy sector in the context of sustainable development (with the example of Ukraine) by means of a new systemic approach to describing the object of management, determining the list and relevant macro indicators in each year for a given perspective.

Section 2 outlines a universal methodology for identifying and strategizing in various areas of national security in view of sustainable development. A systemic approach to describe the object of management is proposed. This approach proves to be expedient as it formalizes the scientific substantiation of safe existence boundaries of the security object, identifies threats and the severity of their impact, justifies determining strategic landmarks of components and indicators by the method of adaptive regulation.

Section 3 describes the structural elements of energy security through components and indicators, for which the limits of safe existence are defined: vectors of threshold values by the method of " t-criterion" (lower threshold, lower optimal, upper optimal, upper threshold); the result of an integrated assessment of the level of energy security, strategic goals, and desirable trajectories of sustainable development according to certain strategic scenarios; imbalances of the constituent structural elements and deviations from the criterion of sustainable development - the average value of the "homeostatic plateau" (lower and upper optimal value); a list of threats by distance from the criterion of sus- 
tainable development and a list of threats by the severity of the impact; and international comparisons of key macro indicators and indicators.

Section 4 discusses the results and their interpretation in terms of the previous research and working hypotheses.

The conclusions present the main results obtained and the possibility of their use for the monitoring and control of the effectiveness of management and authorities' and government's actions.

\section{Materials and Methods}

The energy security should be directly attributed to the areas of national security that ensure the realization of one of the fundamental national interests-sustainable development of the national economy, while ensuring other national interests—state sovereignty and independence [29-46].

The development of a model for assessing the state of energy security proceeds from the definition of energy security as " ... the ability to meet society's energy needs in a technically reliable, cost-effective and environmentally friendly way, to ensure sustainable functioning of the national economy in normal and crisis conditions, to protect state sovereignty in forming and pursuing the policy of the national interests' protection" [47] (p. 47).

To estimate the level of energy security, a universal methodology for identifying the level of various security areas has been used [29]. According to the determined methodology, calculations of the level of energy security of Ukraine for the period from 2000-2018 were carried out [47] by two methods of indicator grouping. Moreover, the dynamics of the integrated index of the system's current state is the starting point for the next stage-strategizing for a given perspective. The methodology for identifying the level of security is based on the applied systems theory and economic cybernetics.

The systemic approach also allows for introducing the strategizing issue into the analysis of energy security problems. The paper will demonstrate the development of a sustainable development strategy in the energy sector of Ukraine until 2030 according to the principle "the future is determined by the trajectory of the future" instead of the principle of classical forecasting, "the past determines the future". The strategizing methodology is based on the method of adaptive control from the theory of management for the synthesis of essential values of indicators that meet the objectives set.

To implement these tasks, a universal methodology of identifying and strategizing in the field of national security is used, which allows for comparing indicators of different security spheres and substantiating strategic scenarios of security development. The methodology is based on the concept of sustainable development from the standpoint of security [29] (pp. 41-46), which contains a general systematic perception of the ways of transition from the current position of the management object to the desired one and includes the following stages:

Identification: determining the structure of the security object; forming a system of indicators; selecting the form of the integrated index; selecting the rationing method; scientific substantiation of dynamic weighting coefficients; determining the limits of safe existence-scientific substantiation of the vector of threshold values; simultaneous integral convolution of indicators and their threshold values; and determining the list and importance of the impact of threats;

Strategizing: goal setting-defining strategic goals; construction of the future trajectory of the desired development; synthesis of strategic landmarks of components and indicators of the security object through the decomposition of integrated indices using adaptive control methods from management theory [29]; and implementation of the "denorming" procedure- the transition from dimensionless indicators to macro indicators in natural units.

To apply the proposed concept, energy security is highlighted as the object of research. As already mentioned, currently, there exists no single methodological approach to outline the energy security domain. Each country uses its own approach for defining the term 
"energy security", determining the scope of regulation, forming a management system, and estimating the level of energy security and threats. At the same time, it is important to note that most researchers use an integrated approach with a high level of subjectivity, taking into account the specific features of the researcher's environment or the environment of the research.

This paper applies a systemic approach to describing energy security, which allows for describing the object of study (energy security) through highlighting its procedural component (functions, processes, material), along with traditional components of the system (elements, connections, structure). This presentation allows for harmonizing the existing approaches for estimating the level of energy security, in particular, estimating security as a state of protectability and the system's capability to adapt to new challenges. [47].

According to the methodology [29], the identification and strategizing of energy security were carried out according to the " $4{ }^{\prime} \mathrm{s}$ " approach, as well as the identification according to the new systemic approach for comparing the levels of security development [47]. The proposed work is devoted to strategizing security development of the energy sector according to a new systemic approach using a modern methodology of strategizing, which was not done in [47], and detailing the analysis performed and the results obtained.

The "status" of energy security will be determined by the "external" observer (relative to the system), perceiving the system from the outside as a comprehensive whole (reflecting the place of this system in a larger system), highlighting important system parameters at a particular time. The status of the system will be described by a set of parameters that will characterize it in relation to the external environment. In fact, this set of parameters will reflect the traditional approach to estimating energy security as a static object of management. The "capability" of the system will be reflected in groups of parameters that describe the functions and processes of the system that occur inside the object and form the parameters that are not perceived by the "external" observer. These groups of parameters should be paid special attention to by the subject of management, as they will reveal the "endemic" laws of the system's performance and indicate the subject of its management decisions and their adequacy.

Determining the structure and system of indicators involves shaping a system of energy security parameters; detailing components and their indicators; and forming the dynamics of indicators and their belonging to stimulators (S), whose increase is desirable, or de-stimulators (D), for which decrease is desirable.

The dynamics and threshold values of indicators were mainly used calculated on the data from the State Statistics Service of Ukraine [48] and model calculations of formal [49] (pp. 81-177) and informal [50] macro indicators. For comparison with other countries, data from the International Energy Agency (IEA) [51], The World Bank [52], and Eurostat [53] were used to substantiate the boundaries of a safe zone of "energy security". The threshold vector was determined taking into account the concept of "homeostatic plateau" [54], a construction for a given sample of the probability density function and calculation of statistical characteristics: mathematical expectation, standard deviation, and asymmetry coefficient [29] (pp. 66-72).

Research and analysis of energy security indicators have revealed the need to improve the formalized description of the threshold vector for lognormal and exponential types of distribution, namely "tail right" and "tail left" [55] (p. 29) (Table 1), with $\mu$ expressing the average value, $\sigma$ denoting mean square deviation, and $t$ borrowed from the Student's $t$-distribution tables [56]. 
Table 1. Formalized threshold vector values *.

\begin{tabular}{ccccc}
\hline $\begin{array}{c}\text { Type of Indicator Probability } \\
\text { Density Function }\end{array}$ & Lower Threshold & Lower Optimal Value & Upper Optimal Value & Upper Threshold \\
\hline Normal & $\mu-t \sigma$ & $\mu-\sigma$ & $\mu+\sigma$ & $\mu+t \sigma$ \\
\hline Lognormal (tail right) & $\mu-t \sigma / k_{a s}$ & $\mu-\sigma / k_{a s}$ & $\mu+\sigma$ & $\mu+t \sigma$ \\
\hline Lognormal (tail left) & $\mu-t \sigma$ & $\mu-\sigma$ & $\mu+\sigma / k_{a s}$ & $\mu+t \sigma / k_{a s}$ \\
\hline Exponential (tail right) & $\mu-\sigma / k_{a s}$ & $\mu$ & $\mu+\sigma$ & $\mu+t \sigma$ \\
\hline Exponential (tail left) & $\mu-t \sigma$ & $\mu-\sigma$ & $\mu$ & $\mu+\sigma / k_{a s}$ \\
\hline
\end{tabular}

${ }^{*} \pm 3 \sigma$ or more is used instead of $t$ for short samples, if values are critical.

Thus, the starting point of the strategizing stage is the stage of identification according to the modern methodology of integrated assessment [31], which provides a multiplicative form of an integrated index, the combined rationing method, and dynamic weights by a combination of a "principal components" method and a "sliding matrix" method.

Performing a step-by-step convolution of indicators, components, and thresholds of energy security, we obtain an integrated multifactor model of energy security in the context of sustainable development in the following form (1):

$$
I_{E n S, t}=\prod_{i=1}^{5} z_{i, t}^{a_{i}} ; P_{i j}=\prod_{j=1}^{4} p_{i j}^{b_{i j}} ; p_{i j}=\left[p_{\text {threshold }, i j}^{\text {lower }} ; p_{\text {optimal }, i j}^{\text {lower }} ; p_{\text {optimal }, i j}^{\text {apper }} ; p_{\text {threshold }, i j}^{\text {apper }}\right]
$$

Note: the formula of the integrated energy security index is given for the case of 5 components and 4 threshold values of indicators.

Determining imbalances, list, and severity of threats. Using the existing dynamics of indicators, integrated indices of sustainable development, and integrated threshold values, it is possible to calculate the deviation of integrated indices of components and indicators of energy security from their average optimal values (homeostatic plateau), which can be considered criteria for sustainable development [29] (p. 195).

To determine the list of threats, two criteria are used:

- by distance from the point of sustainable development (the list and importance of threats are determined);

- by the severity of the impact through the calculation of coefficients of elasticity (the degree of threats' impact is determined).

It is the simultaneous rationing and integral convolution of indicators and their threshold values that allows for comparing on one scale the deviations of integral indices from the corresponding average optimal threshold values (criteria of sustainable development).

To determine the severity of the threat, the coefficients of elasticity of each component and indicators (2) are calculated, which explain the impact of individual components and indicators on the level of energy security (by what percentage will the initial value change when changing $1 \%$ of the input value), and are the necessary data to develop priority measures of influence:

$$
E=\frac{\Delta y}{\Delta x} \cdot \frac{x}{y}
$$

where $x$ is any indicator of sustainable development, $y$ is an integrated indicator, $\Delta x$ is an increase of the corresponding indicator, and $\Delta y$ is increase in the integrated indicator.

Goal setting and strategizing the security level. The strategic vision of sustainable development first involves determining at what distance from the trajectory of sustainable development is the integrated index of energy security, as well as its components, to determine strategic guidelines that condition the desired scenarios of sustainable development, and then, to apply theoretical approaches for justifying strategic goals of achieving sustainable development scenarios. 
Consistently performing integrated convolutions of individual components of energy security, we obtain the dynamics of the integrated index of energy security in the context of sustainable development. It is the simultaneous norming of energy security indicators and their threshold values by a single norming coefficient that makes it possible to compare the dynamics of the integrated index with the integrated threshold values, i.e., to identify the level of energy security.

Such a comparison of the integrated index with the integrated thresholds determines the strategic scenarios of sustainable development in the medium term, for example, until 2030. Thus, for every year we know the desired values of the integral index. The task of strategizing is to solve the inverse problem: at a given value of the integrated index to find the values of components and indicators that provide the desired value of the integrated index, i.e., to do strategic energy security planning applying the principle "the future is determined by trajectory into the future" [29] (pp. 86-92) rather than the classical forecasting principle, "the past determines the future".

To address this issue, there is designed a methodology of strategizing that applies adaptive control methods of the management theory, which allows finding out the necessary values of components and their indicators in the course of the prognosis period each year (Figure 1).

Vector desired component values (indicators) Security

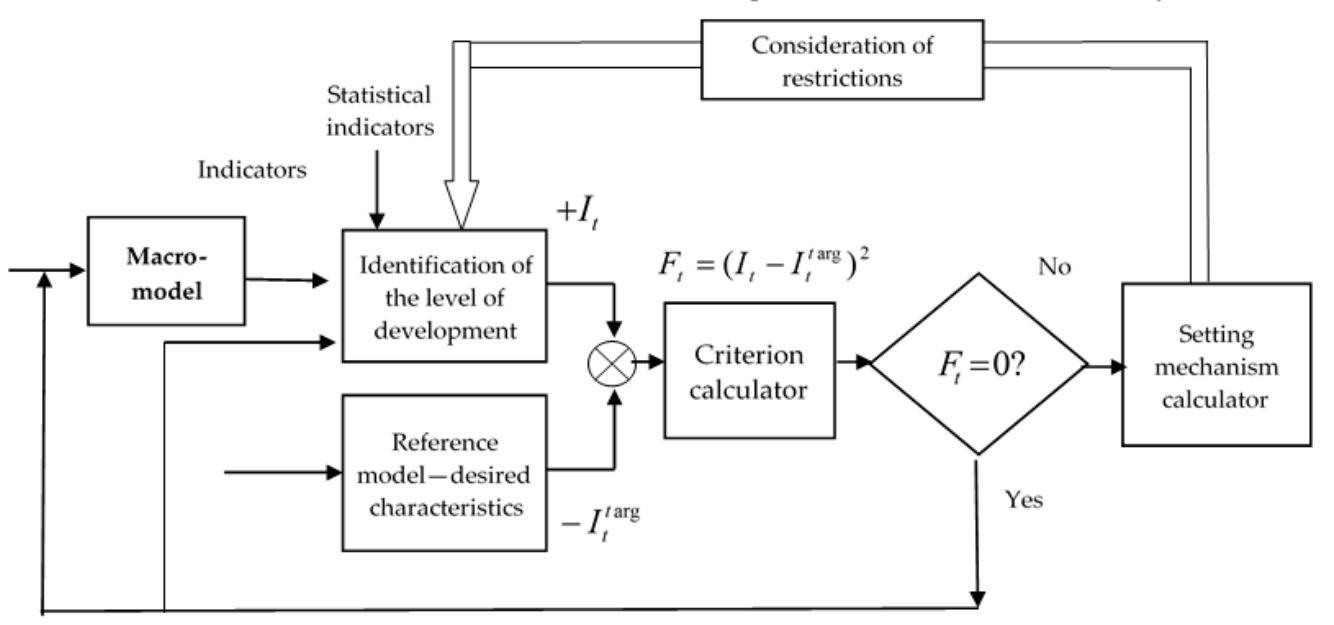

Figure 1. The generalized scheme of adaptive control system with a reference model.

Hence, in order to regulate the components of the integrated index and their indicators it is necessary to find out such values of theirs in the aggregate that determining the values of the integrated indicator within the specified (optimal) values is ensured. Definitely, the methods based, in particular, on the error function gradient are applied in adjusting the model parameters. The adjustment mechanism primarily aims to minimize the quadratic function of the error and its derivatives, and all functions are assumed to be continuous and at least twice differentiated.

\section{Results}

\subsection{A Systemic Approach in Energy Security Research}

The trend of recent years in developing the theory of studying energy security problems is the shift of the researchers' attention from the problems of "statics", to the "dynamics" of systems, from assessing the state of energy security to the system's capability to ensure sustainable operation. For example, A. Cherp and J. Jewell criticize the 4 A's approach because it is outdated and was appropriate to describe the static world that existed before the era of globalization of energy markets and technologies $[20,21]$. 
In agreement with this position, this paper proposes a toolkit for describing energy security, which would reflect both the static and dynamic aspects of the operation of the object studied.

Given the trends in energy markets, further globalization and the development of theoretical foundations of research in this area, the need to focus on the dynamics of change in the system can be emphasized. To this end, we propose the application of a systemic approach to studying the energy security issues.

According to the systemic approach, the selected object of research (management), for our case, the energy security domain, can be represented through a number of components, namely highlighting:

- elements-individual components of the system with a clear functional role;

- connections - the structure of the relationship between the elements of the system;

- functions - the purpose of the elements in the relationship with other elements;

- $\quad$ processes-information and material redistribution of resources between the elements of the system;

- material - the material from which the system is formed.

This description allows for unifying the process of selecting characteristics important for the object's functioning, and also predicting the dynamics of its development, which allows for supplementing the analysis of energy security not only by assessing the current state of parameters but also by forming a development trajectory.

The objectives are defined for all components of the systemic description of the object of management, and relate not only to the goal setting as for the level of primary resources, their exports or imports, energy efficiency, or greenhouse gas emissions by energy sector and national economy, but also relate to the need to transform institutions and mechanisms for the functioning of the energy sector and related industries in the new socio-economic, political, and technological conditions. Additionally, let us separately highlight the component (integrity of the system), which characterizes the described object in terms of an "external" observer or a "bigger" system.

Table 2 presents the components of the systemic description of the country's energy security as an object of management, according to which a set of indicators was formed to evaluate the level and strategizing of energy security.

\subsection{The Results of Determining the Vector of Threshold Values}

For each indicator, a sample of its values for economically developed countries is formed, which can be a model for the future. For a given sample, the probability density function is constructed and statistical characteristics are calculated: mathematical expectation, standard deviation, and asymmetry coefficient. Improving the "t-criterion" method, formulas for determining the vector of threshold values were developed depending on the characteristic type of sample distribution of this indicator (normal, log-normal, exponential), which cover the whole variety of indicators. Defining the boundaries of safe existence (threshold vector) is the most important stage of identification and further strategizing. Without defining the boundaries of safe existence, it is impossible to protect the vital interests of a security facility. It is the comparison of the dynamics of integrated indices with integrated thresholds that makes it possible to identify the security situation and develop appropriate measures. A pair of optimal values determines the "homeostatic plateau" [54], within which there exist the best conditions for the system's existence with negative feedback. Management is to translate the integral index into the range of optimal values, and its subsequent decomposition gives the desired values of all macro indicators, which are scientifically sound instead of subjective expert estimations. 
Table 2. Application of a systemic approach to describing the object of management.

\begin{tabular}{|c|c|c|c|}
\hline Components & Contents of Parameters & & Energy Security Indicators \\
\hline $\begin{array}{l}\text { The integral } \\
\text { system }\end{array}$ & $\begin{array}{l}\text { Capacity. } \\
\text { Procurement. } \\
\text { Dependence. } \\
\text { Integratedness. } \\
\text { Subjectness. }\end{array}$ & $\begin{array}{l}(1) \\
(2) \\
(3) \\
(4) \\
(5) \\
(6) \\
(7) \\
(8)\end{array}$ & $\begin{array}{l}\text { GDP per person, thousand \$/person. (at the current exchange rate) (S); } \\
\text { energy consumption per person, toe/year; (S); } \\
\text { electricity consumption per person, MWh/year, (S); } \\
\text { the cost of energy consumption for the country, \% of GDP; (D); } \\
\text { energy intensity of GDP, toe/\$ 1000; (D); } \\
\text { the level of } \mathrm{CO}_{2} \text { emissions per unit of GDP, kg per \$(D); } \\
\text { the cost of energy imports for the country, \% of GDP; (D); } \\
\text { the level of involvement in EU markets (expert judgement), (S); }\end{array}$ \\
\hline
\end{tabular}

\section{Resource sufficiency:}

(9) oil and oil products, \% (D);

(10) natural gas, \% (D);

(11) coal, \% (D);

Management model $\quad$ (12) nuclear and thermonuclear energy, \% (S);

Organization of the country's (13) hydropower, \% (S);

The system's energy supply system:

(14) solar and wind energy, \% (S); institutional;

elements and infrastructural.

(15) bioenergy, \% (S);

links Provision:

resource (energy resources, technologies);

(16) production processes and infrastructure, \% (expert judgement) (S);

(17) (management processes and infrastructure, \% (expert judgement) (S);

(18) ancillary and service processes and infrastructure, \% (expert judgement) (S);

(19) processes and infrastructure to support facilities at all stages of the life cycle, \% (expert judgement) (S);

(20) information and communication processes and infrastructure, \% (expert judgement) (S);

Functions and roles
Regulating requirements for the provision of target functions. Formalizing requirements for the quality of targeted services.

(21) satisfaction of needs from own sources by types of energy resources, \% of total (S);

(22) a share of the dominant country (supplier) in the total volume of imports by types of energy resources, \% of imports of energy resources; (D);

(23) the level of technological dependence of imports/exports from one source (by type of energy technology), \% (expert judgement) (D);

(24) the level of stocks/reserves from the volumes of annual/monthly consumption by types of energy resources, $\%(S)$;

(25) index of average interruption duration of power supply per consumer (SAIDI), minutes per year; (D)

(26) quality of legislation (its availability), \% (expert judgement) (S);

(27) predictability and sequence of policy changes and regulatory changes, \% (expert judgement) (S);

(28) level of investment of fuel and energy enterprises, \% of fuel and energy sector output; (S);

(29) the level of fixed assets renewal of fuel and energy sector, \%; (D);

(30) level of shadowing in fuel and energy sector, \% of gross value added in fuel and energy sector; (D);

Compliance of a certain process with the established requirements.

Processes $\quad$ Efficiency and effectiveness of the process.

Belonging of the management subject's process to the system.

(31) level of wages, \% of fuel and energy sector output; (S);

(32) the level of shadow capital utilization (extractive industry and production of electricity, gas, and water), \% of the official; (D);

(33) level of shadow consumption of energy resources, \% of GDP of country; (D);

(34) concentration of markets according to the Herfindahl-Hirschman index: (by suppliers) (D);

(35) the level of consumption by housing and communal services, \% of total resources (D);

(36) share of fuel and energy sector in GDP, \% (D);

(37) the level of $\mathrm{CO}_{2}$ emissions at Total Primary Energy Supply (TPES), $\mathrm{tCO}_{2}$ per toe (D);

(38) the carbon capacity of final energy consumption, $\mathrm{CO}_{2} / \mathrm{MJ}$ (D)

(39) quality of public policy, \% (expert judgement) (S);

Qualitative parameters of equipment, resources.

The system's material
Staff qualifications.

Adequacy of DMs (decision makers) to the tasks
(40) quality of services (primary resources, products and energy), \% (expert judgement) (S);

(41) staff quality (technical and managerial), \% (expert judgement) (S);

(42) compliance of political leaders with the tasks facing the system, \% (expert judgement) (S);

Taking into account the available data on the indicators of economically developed countries and using the previously designed equations, the $t$-test technique, and the 
modelling method, there were computed the vectors of the threshold values of energy security indicators of Ukraine in view of sustainable development (Table 3).

Table 3. Vectors of threshold values of energy security indicators.

\begin{tabular}{|c|c|c|c|c|c|c|}
\hline Indicators & $\begin{array}{l}\text { Lower } \\
\text { Threshold }\end{array}$ & $\begin{array}{l}\text { Lower Optimal } \\
\text { Value }\end{array}$ & $\begin{array}{l}\text { Upper Optimal } \\
\text { Value }\end{array}$ & $\begin{array}{l}\text { Upper } \\
\text { Threshold }\end{array}$ & $\begin{array}{l}\text { Normalization } \\
\text { Factor }\end{array}$ & $\begin{array}{l}\text { Ukraine } \\
2018\end{array}$ \\
\hline Integral system & 0.3169 & 0.5062 & 0.7063 & 0.9037 & & 0.3124 \\
\hline $\begin{array}{l}\text { (1) GDP per person, thousand } \\
\text { \$/person (at the current exchange } \\
\text { rate) (S); }\end{array}$ & 15 & 25 & 45 & 80 & 80 & 3.0967 \\
\hline $\begin{array}{l}\text { (2) energy consumption per person, } \\
\text { toe/year; (S); }\end{array}$ & 2.2 & 3.56 & 5.83 & 8.2 & 80.2 & 2.0 \\
\hline $\begin{array}{l}\text { (3) electricity consumption per } \\
\text { person, MWh/year, (S); }\end{array}$ & 2.3 & 5 & 9.5 & 14.2 & 14.2 & 3.1 \\
\hline $\begin{array}{l}\text { (4) the cost of energy consumption } \\
\text { for the country, \% of GDP; (D); }\end{array}$ & 35 & 30 & 20 & 15 & 45 & 28.84 \\
\hline $\begin{array}{l}\text { (5) energy intensity of GDP, toe /\$ } \\
\text { 1000; (D); }\end{array}$ & 0.18 & 0.13 & 0.09 & 0.06 & 0.75 & 0.2686 \\
\hline $\begin{array}{l}\text { (6) the level of } \mathrm{CO}_{2} \text { emissions per } \\
\text { unit of GDP, kg per \$ (D); }\end{array}$ & 0.82 & 0.51 & 0.32 & 0.2 & 3.5 & 1.4 \\
\hline $\begin{array}{l}\text { (7) the cost of energy imports for the } \\
\text { country, } \% \text { of GDP; (D); }\end{array}$ & 10 & 15 & 5 & 0 & 22 & 10.24 \\
\hline $\begin{array}{l}\text { (8) the level of involvement in EU } \\
\text { markets (expert judgement), (S); }\end{array}$ & 20 & 50 & 60 & 80 & 100 & 35 \\
\hline The system's elements and links & 0.4241 & 0.5657 & 0.7458 & 0.9147 & & 0.3487 \\
\hline Resource sufficiency: & 0.2994 & 0.4743 & 0.6637 & 0.8441 & & 0.2327 \\
\hline (9) oil and oil products, $\%$ (D); & 15 & 10.2 & 6.4 & 3.63 & 20 & 14.47 \\
\hline (10) natural gas, \% (D); & 27.6 & 25.2 & 21.65 & 19.73 & 50 & 27.53 \\
\hline (11) coal, \% (D); & 30 & 25.4 & 19.3 & 16.2 & 40 & 29.61 \\
\hline $\begin{array}{l}\text { (12) nuclear and thermonuclear } \\
\text { energy, \% (S); }\end{array}$ & 5.13 & 13.2 & 21.7 & 32.2 & 35 & 23.82 \\
\hline (13) hydropower, \% (S); & 0.8 & 0.9 & 1.0 & 1.2 & 1.2 & 0.9646 \\
\hline (14) solar and wind energy, \% (S); & 3.2 & 6.8 & 13 & 19.7 & 20 & 0.2113 \\
\hline (15) bioenergy, \% (S); & 3.2 & 4.12 & 5.45 & 7 & 7 & 3.4299 \\
\hline $\begin{array}{l}\text { Institutional and organizational } \\
\text { support: }\end{array}$ & 0.6236 & 0.7133 & 0.8485 & 1 & & 0.6309 \\
\hline $\begin{array}{l}\text { (16) production processes and } \\
\text { infrastructure, \% (expert } \\
\text { judgement) (S); }\end{array}$ & 46 & 56 & 80 & 100 & 100 & 42.83 \\
\hline $\begin{array}{l}\text { (17) management processes and } \\
\text { infrastructure, \% (expert } \\
\text { judgement) (S); }\end{array}$ & 66 & 72 & 84 & 100 & 100 & 66.83 \\
\hline $\begin{array}{l}\text { (18) ancillary and service processes } \\
\text { and infrastructure, \% (expert } \\
\text { judgement) (S); }\end{array}$ & 78 & 85 & 90 & 100 & 100 & 84.08 \\
\hline $\begin{array}{l}\text { (19) processes and infrastructure to } \\
\text { support facilities at all stages of the } \\
\text { life cycle, \% (expert judgement) (S); }\end{array}$ & 65 & 70 & 80 & 100 & 100 & 63.75 \\
\hline $\begin{array}{l}\text { (20) information and communication } \\
\text { processes and infrastructure, \% } \\
\text { (expert judgement) (S); }\end{array}$ & 60 & 80 & 95 & 100 & 100 & 67.33 \\
\hline Functions and roles & 0.4287 & 0.6417 & 0.8089 & 0.9305 & & 0.3132 \\
\hline
\end{tabular}


Table 3. Cont.

\begin{tabular}{|c|c|c|c|c|c|c|}
\hline Indicators & $\begin{array}{c}\text { Lower } \\
\text { Threshold }\end{array}$ & $\begin{array}{l}\text { Lower Optimal } \\
\text { Value }\end{array}$ & $\begin{array}{l}\text { Upper Optimal } \\
\text { Value }\end{array}$ & $\begin{array}{l}\text { Upper } \\
\text { Threshold }\end{array}$ & $\begin{array}{l}\text { Normalization } \\
\text { Factor }\end{array}$ & $\begin{array}{l}\text { Ukraine } \\
2018\end{array}$ \\
\hline $\begin{array}{l}\text { (21) satisfaction of needs from own } \\
\text { sources by types of energy resources, } \\
\% \text { of total consumption (S); }\end{array}$ & 65 & 80 & 94 & 100 & 100 & 63.99 \\
\hline $\begin{array}{l}\text { (22) the share of the dominant } \\
\text { country (supplier) in the total } \\
\text { volume of imports by types of } \\
\text { energy resources, \% of imports of } \\
\text { energy resources; (D); }\end{array}$ & 60 & 40 & 20 & 10 & 90 & 41.17 \\
\hline $\begin{array}{l}\text { (23) the level of technological } \\
\text { dependence of import/export on } \\
\text { one source (by types of energy } \\
\text { technologies), \% (expert } \\
\text { judgement) (D); }\end{array}$ & 60 & 40 & 30 & 20 & 85 & 63 \\
\hline $\begin{array}{l}\text { (24) the level of stocks/reserves per } \\
\text { the volumes of annual/monthly } \\
\text { consumption by types of energy } \\
\text { resources, \% (S); }\end{array}$ & 60 & 80 & 100 & 120 & 120 & 25.83 \\
\hline $\begin{array}{l}\text { (25) index of average interruption } \\
\text { duration of power supply per } \\
\text { consumer (SAIDI), minutes per } \\
\text { year; (D) }\end{array}$ & 360 & 250 & 150 & 70 & 770 & 696 \\
\hline $\begin{array}{l}\text { (26) quality of legislation (its } \\
\text { availability), \% (expert } \\
\text { judgement) (S); }\end{array}$ & 50 & 70 & 90 & 100 & 100 & 48.17 \\
\hline $\begin{array}{l}\text { (27) predictability and consistency of } \\
\text { policy changes and regulatory } \\
\text { changes, \% (expert judgement) (S); }\end{array}$ & 50 & 60 & 80 & 100 & 100 & 55 \\
\hline Processes & 0.2782 & 0.4997 & 0.6579 & 0.7807 & & 0.2818 \\
\hline $\begin{array}{l}\text { (28) level of investment of fuel and } \\
\text { energy enterprises, \% of fuel and } \\
\text { energy sector output; (S); }\end{array}$ & 11.6 & 12.8 & 14.6 & 17.7 & 20 & 11.12 \\
\hline $\begin{array}{l}\text { (29) the level of fixed assets renewal } \\
\text { in fuel and energy sector, \%; (D); }\end{array}$ & 4 & 6 & 10 & 15 & 15 & 2.414 \\
\hline $\begin{array}{l}\text { (30) the level of shadowing of fuel } \\
\text { and energy sector, \% gross value } \\
\text { added in fuel and energy sector (D); }\end{array}$ & 25 & 15 & 10 & 5 & 50 & 42.29 \\
\hline $\begin{array}{l}\text { (31) the level of wages, } \% \text { of fuel and } \\
\text { energy sector output; (S); }\end{array}$ & 0.2 & 0.26 & 0.31 & 0.382 & 0.382 & 0.1526 \\
\hline $\begin{array}{l}\text { (32) the level of shadow capital } \\
\text { utilization (mining industry and } \\
\text { production of electricity, gas, and } \\
\text { water), \% of the official; (D); }\end{array}$ & 17 & 10 & 7 & 3.5 & 35 & 29.2 \\
\hline $\begin{array}{l}\text { (33) the level of shadow } \\
\text { consumption of energy resources, \% } \\
\text { of GDP of country; (D); }\end{array}$ & 8 & 5 & 3 & 2 & 17 & 10.7 \\
\hline $\begin{array}{l}\text { (34) concentration of markets } \\
\text { according to the } \\
\text { Herfindahl-Hirschman index: (by } \\
\text { suppliers) (D); }\end{array}$ & 2900 & 1900 & 895 & 260 & 6500 & 2642 \\
\hline $\begin{array}{l}\text { (35) the level of consumption by } \\
\text { housing and communal services, \% } \\
\text { of total resources (D); }\end{array}$ & 20 & 10 & 7 & 5 & 22 & 12.88 \\
\hline $\begin{array}{l}\text { (36) the share of fuel and energy } \\
\text { sector in GDP, \% (D); }\end{array}$ & 10.4 & 9.4 & 7.8 & 7.06 & 12 & 9.45 \\
\hline $\begin{array}{l}\text { (37) the level of } \mathrm{CO}_{2} \text { emissions at } \\
\text { TPES, t } \mathrm{CO}_{2} \text { per calorific value (D); }\end{array}$ & 2.15 & 1.8 & 1.38 & 0.91 & 2.5 & 1.9 \\
\hline $\begin{array}{l}\text { (38) the carbon capacity of final } \\
\text { energy consumption, } \mathrm{g} \mathrm{CO}_{2} / \mathrm{MJ} \text { (D). }\end{array}$ & 100 & 80 & 60 & 50 & 110 & 82 \\
\hline
\end{tabular}


Table 3. Cont.

\begin{tabular}{|c|c|c|c|c|c|c|}
\hline Indicators & $\begin{array}{c}\text { Lower } \\
\text { Threshold }\end{array}$ & $\begin{array}{l}\text { Lower Optimal } \\
\text { Value }\end{array}$ & $\begin{array}{l}\text { Upper Optimal } \\
\text { Value }\end{array}$ & $\begin{array}{c}\text { Upper } \\
\text { Threshold }\end{array}$ & $\begin{array}{l}\text { Normalization } \\
\text { Factor }\end{array}$ & $\begin{array}{l}\text { Ukraine } \\
2018\end{array}$ \\
\hline The system's material & 0.6439 & 0.7537 & 0.9102 & 1 & & 0.3917 \\
\hline $\begin{array}{l}\text { (39) quality of public policy, \% } \\
\text { (expert judgement) (S); }\end{array}$ & 70 & 80 & 90 & 100 & 100 & 36.42 \\
\hline $\begin{array}{l}\text { (40) quality of services (primary } \\
\text { resources, products and energy), \% } \\
\text { (expert judgement) (S); }\end{array}$ & 60 & 70 & 90 & 100 & 100 & 68.33 \\
\hline $\begin{array}{l}\text { (41) staff quality (technical and } \\
\text { managerial), \% (expert } \\
\text { judgement) (S); }\end{array}$ & 60 & 70 & 90 & 100 & 100 & 43.33 \\
\hline $\begin{array}{l}\text { (42) compliance of political leaders } \\
\text { with the tasks facing the system, \% } \\
\text { (expert judgement) (S); }\end{array}$ & 70 & 85 & 95 & 100 & 100 & 28.17 \\
\hline
\end{tabular}

\subsection{The Results of an Integrated Assessment of the Level of Energy Security}

The results of the calculations indicate an unsatisfactory level of the integrated energy security index in comparison with the integrated threshold values for the country as a whole during the entire analysis period (2000-2018) [47] (pp. 76-77) (Figure 2).

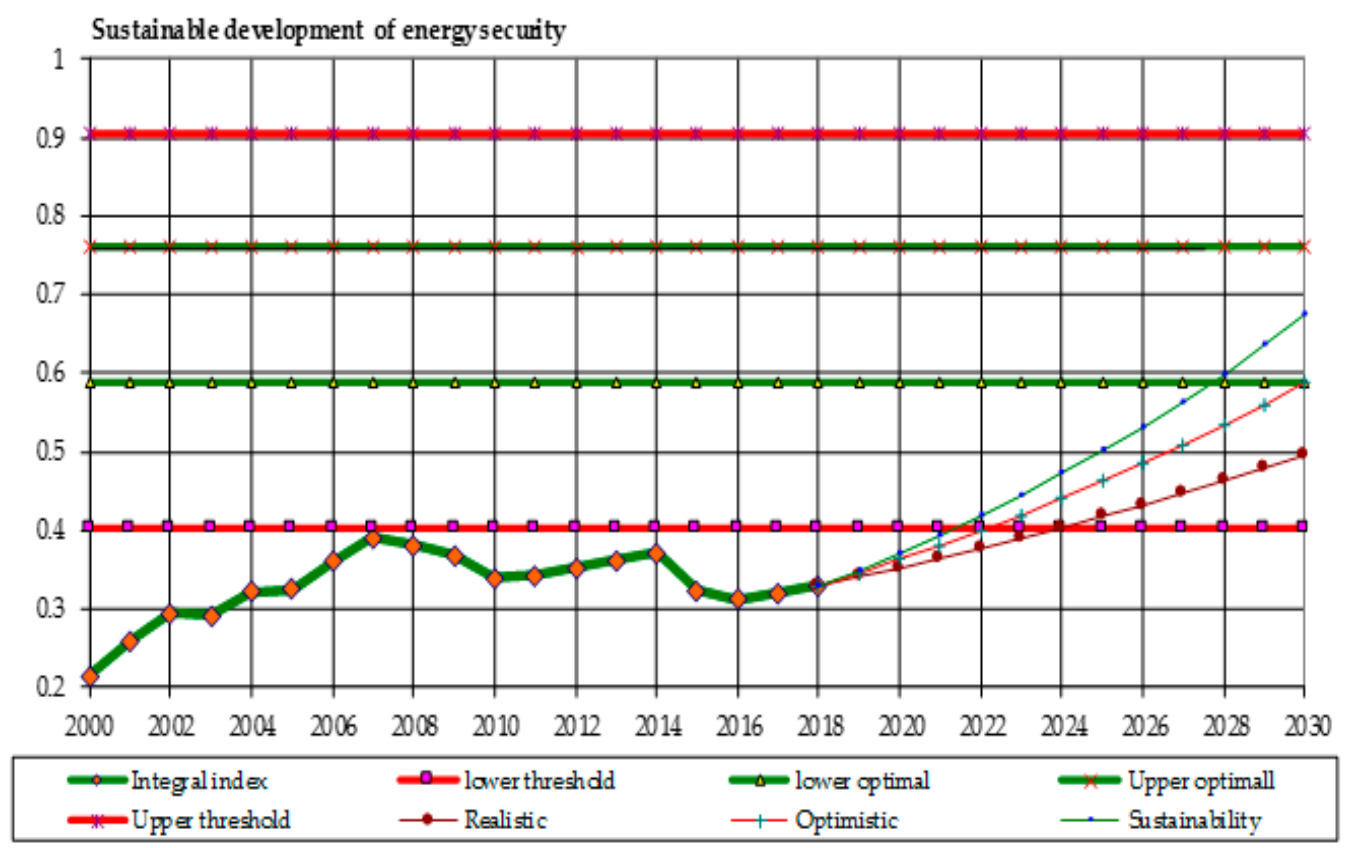

Figure 2. The level of energy security of Ukraine (with strategic scenarios).

At the same time, the conducted research demonstrates that certain components of the integrated energy security index of Ukraine lag behind the optimal level, and accordingly, pose a threat at the end of 2018.

It should be noted that such components (Figure 2) as the integral system and the system's elements and links have a steady positive tendency to approach the target values. At the same time, the dynamics of other components of the systemic description of energy security functions and roles, processes, and material of the system reflect instability in achieving the strategic goals of energy security. Moreover, there is a significant deterioration of the integrated index component, which reflects the quality of the system's material (technical condition of power engineering, consistency and quality of energy policy, and compliance of decision-makers with their positions in the management system). 


\subsection{Determining the List and Severity of the Threats Impact on Energy Security}

To determine the list of threats, two criteria are used:

By distance from the point of sustainable development (the list and importance of threats is determined) (Figure 3).

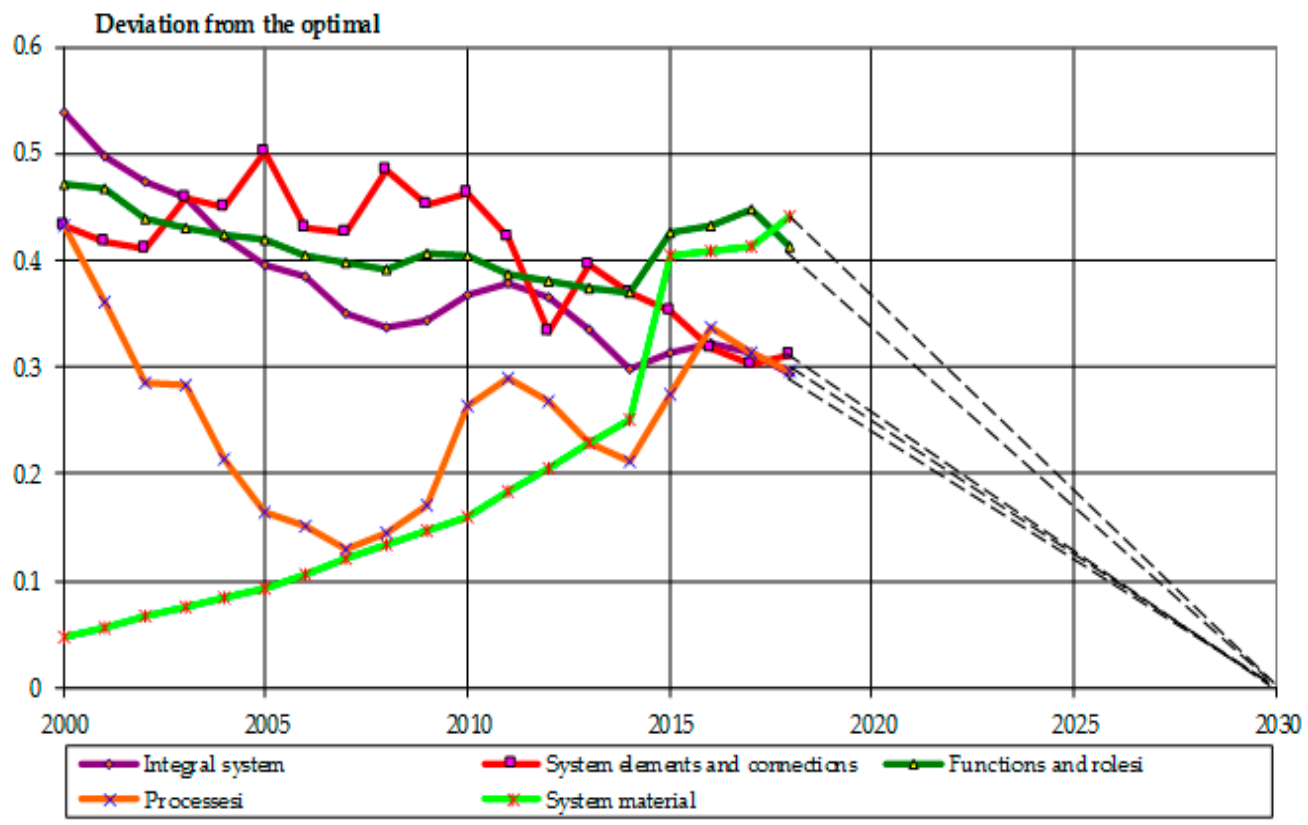

Figure 3. Dynamics of integral indices deviations from the criteria of sustainable development.

The main task of sustainable development is to eliminate imbalances, i.e., to reduce to zero the deviation of each component of sustainable development, for example, by the end of 2030. Equalizing disproportion and zeroing deviations from the criterion of sustainable development will ensure balanced sustainable development. A clearer picture of imbalances and a list of threats by importance can be obtained from the relevant indicators of each component: of the 42 energy security indicators, 40 are a threat, 22 of them are in the critical (red) zone (below the lower threshold), 18 in the crisis (orange) zone (between the lower threshold and lower optimal), and 2 indicators are in the optimal (green) zone.

By the severity of the impact through calculating coefficients of elasticity (determined by the degree of threats' impact).

To determine the threats' severity in accordance with the formula (2), the coefficients of elasticity of each component and their indicators are calculated, which explain the degree of impact of individual components and their indicators on energy security (by what percentage will the initial value change when changing $1 \%$ of the input value) and which provide the information needed to develop priority impact actions.

The list of the first ten critical threats by distance from the criterion of sustainable development (importance of threats) and the importance of their impact on the state of energy security through the calculation of elasticity coefficients are given in Table 4 .

All components of energy security and these indicators are critical threats, because they are in the red zone-below or on the verge of the lower threshold. Changing these components and the relevant critical indicators would have a very strong impact on energy security, so they should be given special attention to while implementing reforms. Changing from negative to positive dynamics of these components and indicators is a priority of the Government of Ukraine, which will become an objective indicator of the ongoing reforms' effectiveness in the field of energy security. 
Table 4. Critical threats and the importance of their impact on the level of energy security.

\begin{tabular}{|c|c|c|}
\hline $\begin{array}{l}\text { Components and Indicators of Energy Security- } \\
\text { Threats According to a Distance from the } \\
\text { Criterion of Sustainable Development }\end{array}$ & $\begin{array}{c}\text { Components and Indicators of Energy Security- } \\
\text { Threats by Severity of Impact }\end{array}$ & $\begin{array}{l}\text { Coefficient of } \\
\text { Elasticity }\end{array}$ \\
\hline \multicolumn{3}{|c|}{ By components } \\
\hline 1. The system's material & 1. The system's elements and links & 0.2279 \\
\hline 2. Functions and roles & 2. Processes & 0.2256 \\
\hline 3. The system's elements and links & 3. The system's material & 0.2259 \\
\hline 4. Processes & 4. Functions and roles & 0.2229 \\
\hline 5. The integral system & 5. The integral system & 0.0964 \\
\hline \multicolumn{3}{|l|}{ By indicators } \\
\hline $\begin{array}{l}\text { 1. Index of duration of average interruption } \\
\text { duration of power supply per consumer (SAIDI), } \\
\text { minutes per year; }\end{array}$ & $\begin{array}{l}\text { 1. Index of duration of average interruption } \\
\text { duration of power supply per consumer (SAIDI), } \\
\text { minutes per year; }\end{array}$ & -0.3591 \\
\hline $\begin{array}{l}\text { 2. Political leaders' compliance of with the tasks } \\
\text { facing the system }\end{array}$ & $\begin{array}{l}\text { 2. Level of shadowing of fuel and energy sector, \% } \\
\text { gross value added in fuel and energy sector }\end{array}$ & -0.1439 \\
\hline $\begin{array}{l}\text { 3. Level of shadowing of fuel and energy sector, } \% \\
\text { gross value added in fuel and energy sector }\end{array}$ & $\begin{array}{l}\text { 3. The level of shadow capital utilization (mining } \\
\text { industry and production of electricity, gas, and } \\
\text { water), } \% \text { of the official; }\end{array}$ & -0.1344 \\
\hline
\end{tabular}

4. The level of shadow capital utilization (mining industry and production of electricity, gas, and water), $\%$ of the official;

4. The level of technological dependence

5. The level of stocks/reserves per the volumes of annual/monthly consumption by types of energy resources, $\%$

\begin{tabular}{lll}
\hline 6. Quality of public policy & 6. Quality of public policy & 0.0638 \\
\hline 7. Solar and wind power industry & $\begin{array}{l}\text { 7. Political leaders' compliance of with the tasks } \\
\text { facing the system }\end{array}$ & 0.0636 \\
\hline $\begin{array}{l}\text { 8. GDP per 1 person, thousand \$/person (at the } \\
\text { current exchange rate) }\end{array}$ & $\begin{array}{l}\text { 8. Cost of energy resources for the country, } \% \\
\text { of GDP }\end{array}$ & -0.0609 \\
\hline $\begin{array}{l}\text { 9. The level of shadow consumption of energy } \\
\text { resources, \% of GDP of Ukraine; }\end{array}$ & 9. The share of fuel and energy sector in GDP, $\%$ & -0.0594 \\
\hline $\begin{array}{l}\text { 10. The level of fixed assets renewal in fuel and } \\
\text { energy sector, } \% ;\end{array}$ & 10. Resource adequacy of oil and oil products, $\%$ & -0.0576 \\
\hline
\end{tabular}

\subsection{Energy Security Strategizing}

Well-known approaches to strategic planning mainly use methods of classical forecasting of integrated indices: "the past determines the future". Polynomials (even third order) or regression equations are used for this purpose, which exhausts the complexity of such a multidimensional concept as energy security and sustainable development, and discredits economic-mathematical modeling.

Traditional prediction methods are definitely unable to work here. First, prediction stipulates the current tendencies to continue in the future; second, prediction is sure to entail errors; third, it is crucial to find out what changes of the components and indicators of sustainable development or security can result in the required development state. The existing need in other ways to approach this situation is met by the approach presented in this research grounded on the philosophy that forecasting future stems not from the past but rather is stipulated by determining the trajectory into the future [29] (pp. 86-92).

After obtaining the dynamics of the integrated index of the system's state, it is necessary to determine the strategic goal (or several goals, for example, for realistic and 
optimistic scenarios and for scenarios of balanced sustainable development) depending on the ratio of the integrated index to the integrated thresholds that characterize the optimal, pre-crisis, crisis, or critical state of the system.

Thus, there are three development scenarios, for example, by 2030 (see Figure 2):

- Realistic-reaching the middle level between the lower threshold and the lower optimal values.

- Optimistic is understood as an ability to attain the level of the lower optimal value (that is, to get into the EU nation-states' optimal zone.

- Balanced sustainable development-achieving the level of average optimal value (homeostatic plateau) - the criterion of sustainable development.

Solving the inverse problem of synthesizing the required values of components and indicators at a given value of the integrated index, we obtain the future dynamics of components and indicators of energy security (Figure 4) (Table 5).

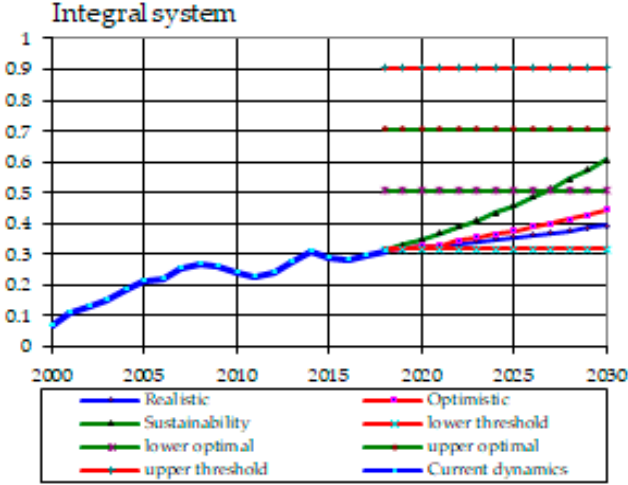

(a)

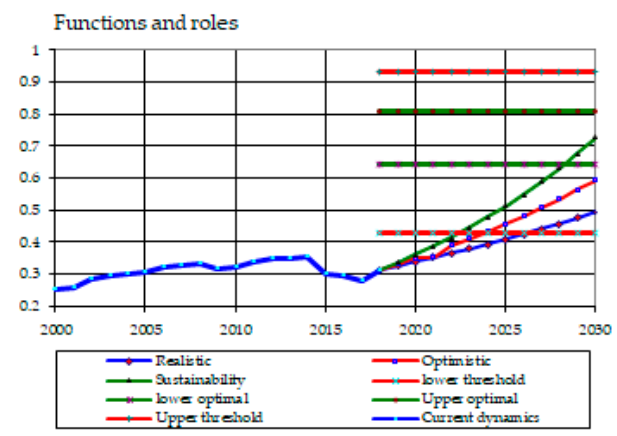

(c)

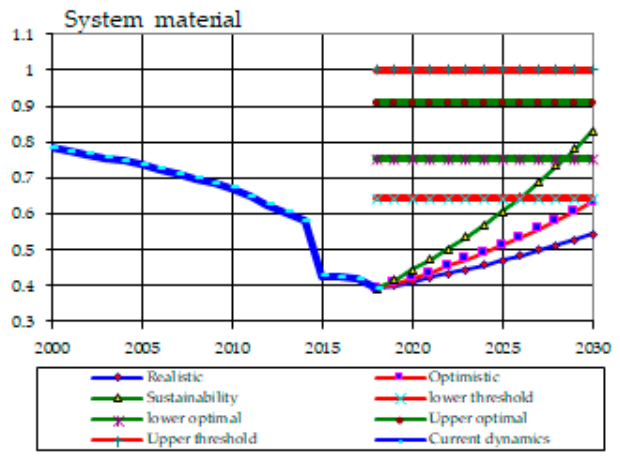

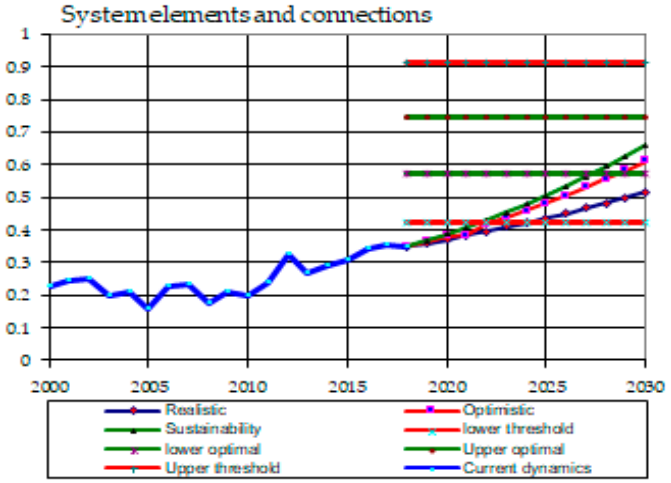

(b)

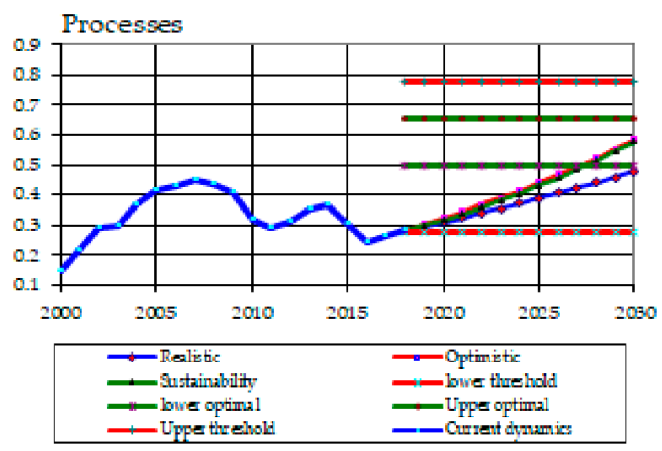

(d)

(e)

Figure 4. Future dynamics of energy security components of Ukraine. 
Table 5. Estimation of strategic values of components and indicators of energy security at the end of 2030.

\begin{tabular}{|c|c|c|c|}
\hline Indicators & Scenario 1 & Scenario 2 & Scenario 3 \\
\hline I. The integral system & 0.3939 & 0.4438 & 0.6062 \\
\hline (1) GDP per person, thousand \$/person (at the current exchange rate) (S); & 12.83 & 19.26 & 35.0 \\
\hline (2) energy consumption per person, toe/year; (S); & 2.439 & 2.861 & 4.695 \\
\hline (3) electricity consumption per person, MWh/year, (S); & 3.933 & 4.714 & 7.25 \\
\hline (4) the cost of energy consumption for the country, \% of GDP; (D); & 27.28 & 25.68 & 25.0 \\
\hline (5) energy intensity of GDP, toe/1000 \$; (D); & 0.2526 & 0.2354 & 0.11 \\
\hline (6) the level of $\mathrm{CO}_{2}$ emissions per unit of GDP, $\mathrm{kg}$ per \$ (D); & 1.318 & 1.230 & 0.415 \\
\hline (7) the cost of energy imports for the country, \% of GDP; (D); & 9.719 & 9.162 & 7.5 \\
\hline (8) the level of involvement in EU markets (expert judgement), (S); & 38.83 & 42.73 & 55.0 \\
\hline II. The system's elements and links & 0.5173 & 0.6133 & 0.6607 \\
\hline Resource sufficiency: & 0.4247 & 0.5409 & 0.5691 \\
\hline (9) oil and oil products, \% (D); & 13.12 & 10.86 & 8.3 \\
\hline (10) natural gas, $\%(\mathrm{D})$; & 25.28 & 21.08 & 23.42 \\
\hline (11) coal, \% (D); & 27.14 & 22.96 & 22.35 \\
\hline (12) nuclear and thermonuclear energy, \% (S); & 24.89 & 26.98 & 17.45 \\
\hline (13) hydropower, \% (S); & 0.973 & 0.989 & 0.950 \\
\hline (14) solar and wind energy, \% (S); & 4.5 & 8.04 & 9.9 \\
\hline (15) bioenergy, \% (S); & 3.72 & 4.27 & 4.78 \\
\hline Institutional and organizational support: & 0.6909 & 0.7374 & 0.7809 \\
\hline (16) production processes and infrastructure, \% (expert judgement) (S); & 51.02 & 57.27 & 68.0 \\
\hline (17) management processes and infrastructure, \% (expert judgement) (S); & 72.26 & 76.63 & 78.0 \\
\hline (18) ancillary and service processes and infrastructure, \% (expert judgement) (S); & 88.23 & 91.63 & 87.5 \\
\hline $\begin{array}{l}\text { (19) processes and infrastructure to support facilities at all stages of the life cycle, \% } \\
\text { (expert judgement) (S); }\end{array}$ & 69.35 & 73.84 & 75.0 \\
\hline $\begin{array}{l}\text { (20) information and communication processes and infra-structure, \% (expert } \\
\text { judgement) (S); }\end{array}$ & 71.21 & 74.37 & 87.5 \\
\hline III. Functions and roles & 0.4925 & 0.5924 & 0.7253 \\
\hline $\begin{array}{l}\text { (21) satisfaction of needs from own sources by types of energy resources, \% of total } \\
\text { consumption (S); }\end{array}$ & 66.49 & 68.75 & 87.0 \\
\hline $\begin{array}{l}\text { (22) the share of the dominant country (supplier) in the total volume of imports by } \\
\text { types of energy resources, \% of imports of energy resources; (D); }\end{array}$ & 33.31 & 26.76 & 30.0 \\
\hline $\begin{array}{l}\text { (23) the level of technological dependence of import/export on one source (by types } \\
\text { of energy technologies), \% (expert judgement) (D); }\end{array}$ & 49.72 & 40.39 & 35.0 \\
\hline $\begin{array}{l}\text { (24) the level of stocks/reserves per the volumes of annual/monthly consumption by } \\
\text { types of energy resources, \% (S); }\end{array}$ & 45.79 & 59.21 & 90.0 \\
\hline $\begin{array}{l}\text { (25) index of average interruption duration of power supply per consumer (SAIDI), } \\
\text { minutes per year; (D) }\end{array}$ & 492.1 & 383.6 & 200.0 \\
\hline (26) quality of legislation (its availability), \% (expert judgement) (S); & 57.45 & 65.06 & 80.0 \\
\hline $\begin{array}{l}\text { (27) predictability and consistency of policy changes and regulatory changes, } \% \\
\text { (expert judgement) (S); }\end{array}$ & 62.83 & 69.44 & 70.0 \\
\hline IV. Processes & 0.4781 & 0.5847 & 0.5788 \\
\hline $\begin{array}{l}\text { (28) level of investment of fuel and energy enterprises, \% of fuel and energy sector } \\
\text { output; (S); }\end{array}$ & 13.2 & 14.73 & 13.7 \\
\hline (29) the level of fixed assets renewal in fuel and energy sector, \%; (D); & 6.08 & 8.05 & 8.0 \\
\hline $\begin{array}{l}\text { (30) level of shadowing of fuel and energy sector, \% gross value added in fuel and } \\
\text { energy sector; (D); }\end{array}$ & 28.73 & 21.58 & 12.5 \\
\hline (31) the level of wages, \% of fuel and energy sector output; (S); & 0.2098 & 0.2486 & 0.29 \\
\hline $\begin{array}{l}\text { (32) the level of shadow capital utilization (mining industry and production of } \\
\text { electricity, gas, and water), \% of the official; (D); }\end{array}$ & 19.92 & 14.96 & 8.5 \\
\hline (33) the level of shadow consumption of energy resources, \% of GDP of country; (D); & 8.84 & 7.54 & 4.0 \\
\hline $\begin{array}{l}\text { (34) concentration of markets according to the Herfindahl-Hirschman index: (by } \\
\text { suppliers) (D); }\end{array}$ & 2232.1 & 1917.7 & 1397.5 \\
\hline $\begin{array}{l}\text { (35) the level of consumption by housing and communal services, } \% \text { of total resources } \\
\text { (D); }\end{array}$ & 9.78 & 7.65 & 8.5 \\
\hline (36) the share of fuel and energy sector in GDP, \% (D); & 7.61 & 6.48 & 8.6 \\
\hline (37) the level of $\mathrm{CO}_{2}$ emissions at TPES, t $\mathrm{CO}_{2}$ per calorific value (D); & 1.465 & 1.199 & 1.59 \\
\hline (38) the carbon capacity of final energy consumption, $\mathrm{g} \mathrm{CO}_{2} / \mathrm{MJ}$ (D); & 72.22 & 65.52 & 70.0 \\
\hline
\end{tabular}


Table 5. Cont.

\begin{tabular}{lccc}
\hline \multicolumn{1}{c}{ Indicators } & Scenario 1 & Scenario 2 & Scenario 3 \\
\hline V. The system's material & 0.5444 & 0.6337 & 0.8319 \\
(39) quality of public policy, \% (expert judgement) (S); & 51.8 & 61.22 & 85.0 \\
(40) quality of services (primary resources, products and energy), \% (expert & 73.25 & 76.74 & 80.0 \\
judgement) (S); & 56.71 & 65.21 & 80.0 \\
(41) staff quality (technical and managerial), \% (expert judgement) (S); & 46.76 & 57.48 & 90.0 \\
(42) compliance of political leaders with the tasks facing the system, \% (expert & & \\
judgement) (S); & &
\end{tabular}

Applying this to the obtained indicators of the norming formula in reverse order, we obtain the dynamics of macro indicators in natural units, the most important of which are given in Table 6. These indicators and macro indicators are strategic guidelines for the future state of Ukraine's energy security.

Table 6. Evaluation of strategic landmarks of key macro indicators of energy security of Ukraine at the end of 2030.

\begin{tabular}{|c|c|c|c|c|}
\hline Indicator & 2018 & Scenario 1 & Scenario 2 & Scenario 3 \\
\hline 1. Nominal GDP, UAH billion & 3558.7 & $16,126.2$ & $24,214.6$ & $44,065.2$ \\
\hline 2. Real GDP, \% annual growth & 3.3 & 3.5 & 7.07 & 12.55 \\
\hline $\begin{array}{l}\text { 3. Gross value added in the fuel and energy sector, } \\
\text { UAH billion }\end{array}$ & 336.2 & 1228.4 & 1567.7 & 3790.7 \\
\hline $\begin{array}{l}\text { 4. Real gross value added in the fuel and energy } \\
\text { sector, } \% \text { annual growth }\end{array}$ & 1.0 & -1.96 & 0.05 & 7.69 \\
\hline $\begin{array}{l}\text { 5. Shadow gross value added in the fuel and energy } \\
\text { sector, UAH billion }\end{array}$ & 142.2 & 352.9 & 338.4 & 473.4 \\
\hline $\begin{array}{l}\text { 6. Capital investments of the fuel and energy } \\
\text { complex, UAH billion }\end{array}$ & 90.85 & 381.6 & 513.3 & 1038.6 \\
\hline $\begin{array}{l}\text { 7. The amount of shadow consumption of energy } \\
\text { resources, UAH billion }\end{array}$ & 380.9 & 1425.7 & 1825.1 & 1762.6 \\
\hline 8. Nominal salary in the fuel and energy sector, UAH & 11,424 & 110,619 & 133,088 & 187,105 \\
\hline 9. The amount of $\mathrm{CO}_{2}$ emissions, $\mathrm{Mt}$. & 183.2 & 842.6 & 1217.9 & 580.6 \\
\hline
\end{tabular}

According to calculations, all the proposed scenarios provide an approximation to the level of sustainable development to varying degrees and the corresponding annual economic growth:

- realistic scenario (1) $-3.5 \%$ increase in real GDP and $-1.96 \%$ increase in the real calorific value of the fuel and energy sector;

- $\quad$ optimistic scenario (2)-7.07\% and 0.05\%;

- $\quad$ balanced sustainable development (3): $12.55 \%$ and $7.69 \%$.

The first two scenarios reduce but leave imbalances in the development of components and indicators in contrast to balanced sustainable development.

\subsection{International Comparisons}

Strategic guidelines for sustainable development and its components, which are determined taking into account the sensitivity of each component's impact on the integrated index, are the goal of strategic planning for the medium or long term. It is obvious that the calculated strategic values of indicators (these are relative values), which are determined by the ratio of macro-indicators, can be obtained by many of their values, so to compare the scenarios it is necessary to link to the strategic values of some of the most important macroindicators, relative to which international comparisons of Ukraine's strategic scenarios can be made. 
Taking some assumptions about future values of population size, exchange rate, coefficient of manufacturability (ratio of GDP to output), GDP deflators by country and fuel and energy complex, and others (Table 7), we can obtain the values of GDP and output, relative to which other macro-indicators of energy security are calculated.

Table 7. Assumptions about some macro indicators for Ukraine.

\begin{tabular}{|c|c|c|c|c|c|c|c|}
\hline \multirow{2}{*}{ Indicators/Year } & \multirow{2}{*}{$\begin{array}{l}\text { Population Size, } \\
\text { Man. People }\end{array}$} & \multirow{2}{*}{$\begin{array}{c}\text { Exchange Rate, } \\
\text { UAH/USD }\end{array}$} & \multicolumn{3}{|c|}{ Coefficient of Manufacturability } & \multirow{2}{*}{$\begin{array}{l}\text { GDP } \\
\text { Deflator }\end{array}$} & \multirow{2}{*}{$\begin{array}{l}\text { Deflator of Gross Value } \\
\text { Added in Fuel and } \\
\text { Energy Sector }\end{array}$} \\
\hline & & & Scenario 1 & Scenario 2 & Scenario 3 & & \\
\hline 2019 & 42.028 & 25.8436 & 0.4118 & 0.4147 & 0.4188 & 1.081 & 1.121 \\
\hline 2020 & 41.854 & 26.3088 & 0.4129 & 0.4179 & 0.4262 & 1.075 & 1.115 \\
\hline 2021 & 41.68 & 26.7823 & 0.4141 & 0.4212 & 0.4335 & 1.1 & 1.14 \\
\hline 2022 & 41.506 & 27.2644 & 0.4152 & 0.4244 & 0.4409 & 1.1 & 1.14 \\
\hline 2023 & 41.333 & 27.7552 & 0.4164 & 0.4276 & 0.4483 & 1.1 & 1.14 \\
\hline 2024 & 41.161 & 28.2548 & 0.4175 & 0.4308 & 0.4557 & 1.1 & 1.14 \\
\hline 2025 & 40.990 & 28.7634 & 0.4186 & 0.4340 & 0.4631 & 1.1 & 1.14 \\
\hline 2026 & 40.819 & 29.2811 & 0.4197 & 0.4372 & 0.4705 & 1.1 & 1.14 \\
\hline 2027 & 40.649 & 29.8082 & 0.4209 & 0.4405 & 0.4778 & 1.1 & 1.14 \\
\hline 2028 & 40.480 & 30.3447 & 0.4220 & 0.4437 & 0.4852 & 1.1 & 1.14 \\
\hline 2029 & 40.311 & 30.8909 & 0.4232 & 0.4469 & 0.4926 & 1.1 & 1.14 \\
\hline 2030 & 40.144 & 31.4470 & 0.4250 & 0.4500 & 0.5000 & 1.1 & 1.14 \\
\hline
\end{tabular}

Performing forecast calculations of GDP per capita (thousand US dollars) at the current exchange rate for the world's leading countries, taking into account the average growth rate, the dynamics of the GDP deflator over the past 10 years, and the exchange rate devaluation by $1.8 \%$ per year (Table 8 ), it is possible to compare strategic goals for Ukraine in the medium term-until 2030 for different development scenarios (Figure 5).

Table 8. Average growth rates of real GDP and GDP deflator of the world's leading countries *.

\begin{tabular}{cccccccc}
\hline Country & The U.S. & Germany & France & The RF & China & Poland & Georgia \\
\hline GDP growth rate, $\%$ & 2.0 & 1.9 & 1.2 & 1.8 & 7.6 & 3.7 & 4.9 \\
\hline GDP deflator & 1.0167 & 1.018 & 1.01 & 1.0898 & 1.0265 & 1.0245 & 1.056 \\
\hline
\end{tabular}

* Calculated by the authors according to the data of International Monetary Fund [57] and Eurostat [53].

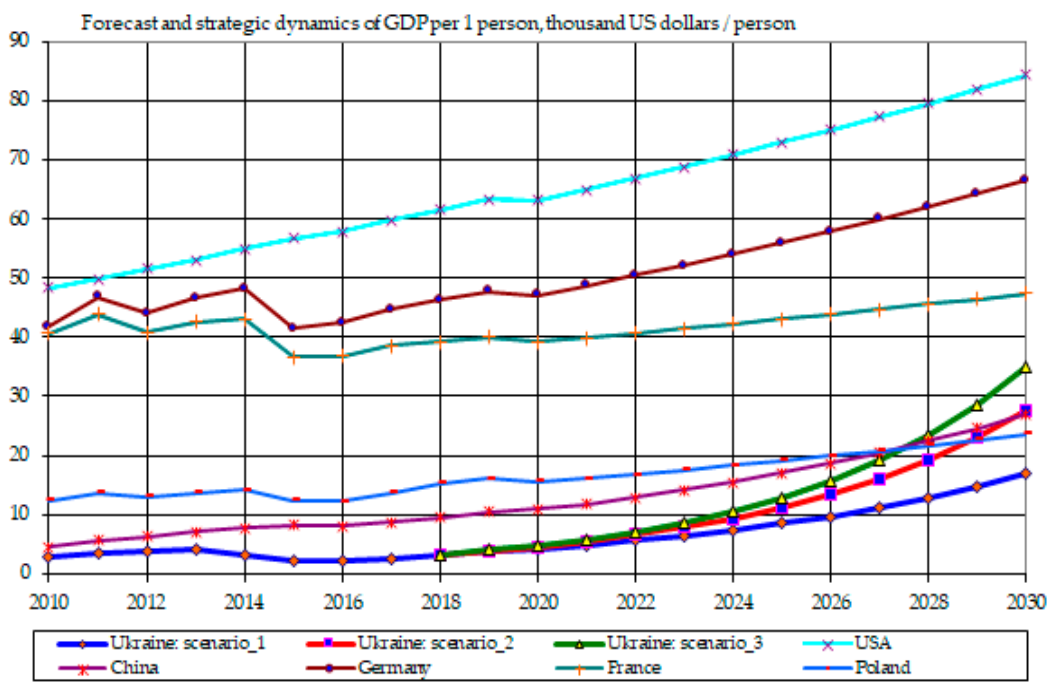

Figure 5. Dynamics of GDP per capita in Ukraine and in the leading countries of the world. 
According to calculations, the first cluster of the indicator "GDP per capita" consists of three countries: the United States, Germany and France, the second covers Poland and China; the third is Ukraine. According to the realistic scenario, Ukraine is forever behind Poland and China; according to the optimistic scenario, Ukraine can catch up with Poland in 2029. According to balanced sustainable development, Ukraine can catch up with Poland in 2027 and China in 2028.

In terms of nominal GDP at the current exchange rate, there are also three clusters (Figure 6).

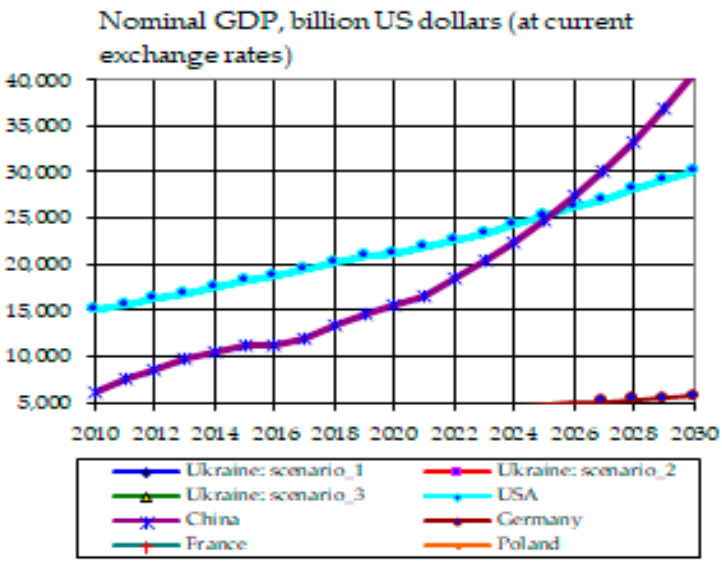

(a)

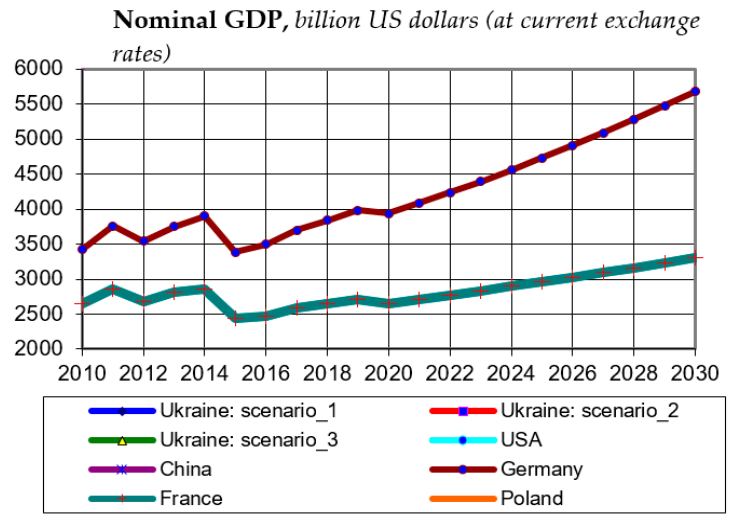

(b)

Nominal GDP, billion US dollars (at current exchange rates)

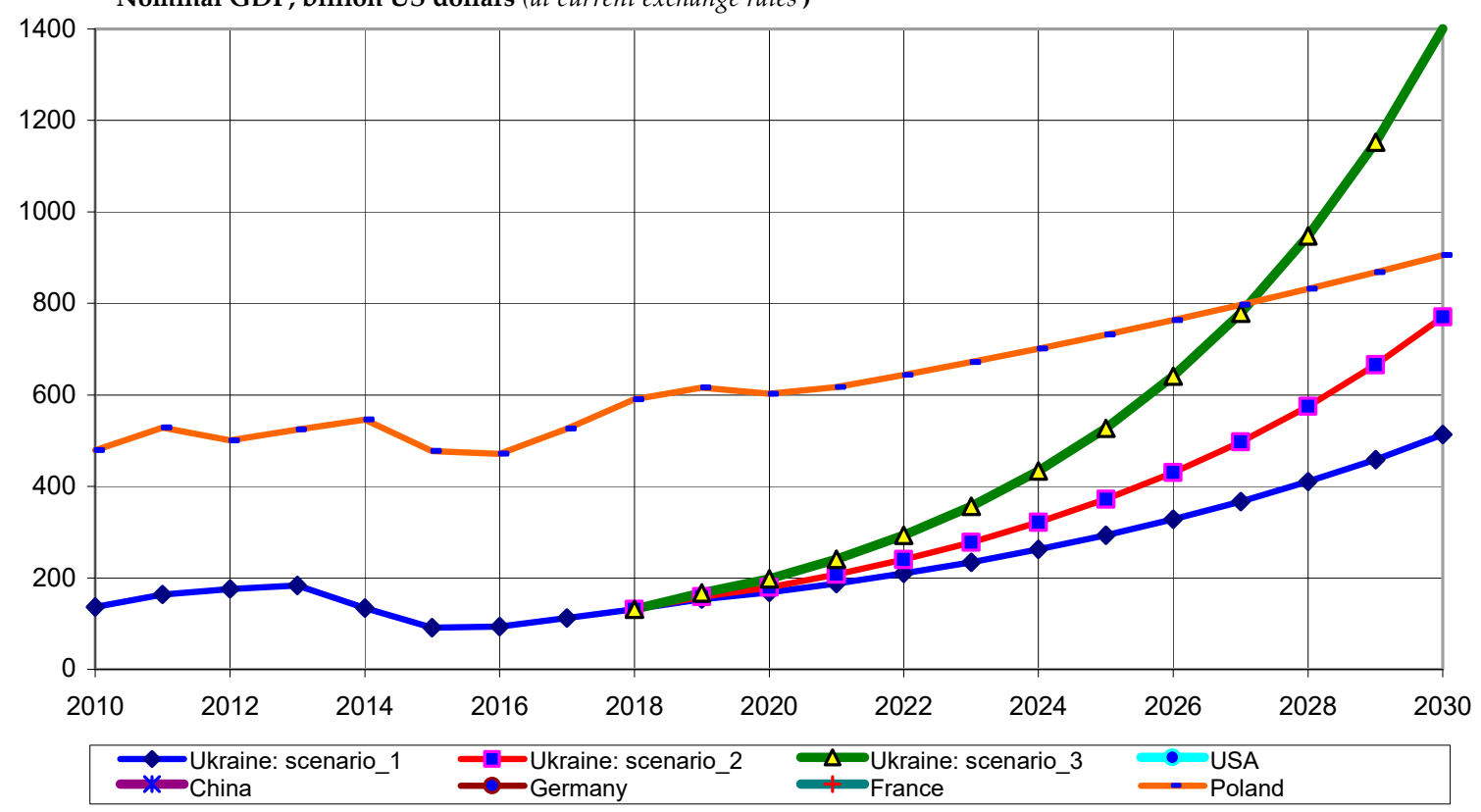

(c)

Figure 6. Dynamics of nominal GDP of Ukraine and the leading countries of the EU and the world: (a) first-the United States and China, with China catching up and overtaking the United States in 2025 and becoming the new world leader in terms of nominal GDP; (b) second-Germany and France; (c) third-Poland and Ukraine (Figure 6c).

According to a realistic scenario, Ukraine will be able to catch up with Poland in 2035; optimistically-in 2029; for balanced sustainable development-in 2027.

Similar comparisons made on the basis of energy indicators, which are included in the integrated index of the energy security level, allow for defining clearly the tasks of implementing the public policy in this domain. In addition, the developed methodology 
allows for periodic evaluation of the current level, determining the priority of management influences, and evaluating the effectiveness of the taken decisions' impact on the achievement of target values.

To understand the security state in Ukraine in comparison with the world's leading countries, the data are presented on the three most complex indicators (see Figures 7-9): GDP per capita at the current exchange rate (characterizes the level of economic development of the country), electricity consumption per capita (indicates the level of economic and technological development of the country, availability of modern equipment for the population), and the level of $\mathrm{CO}_{2}$ emissions from Total Primary Energy Supply TPES (characterizes the level of negative impact on the environment by the primary energy resources).

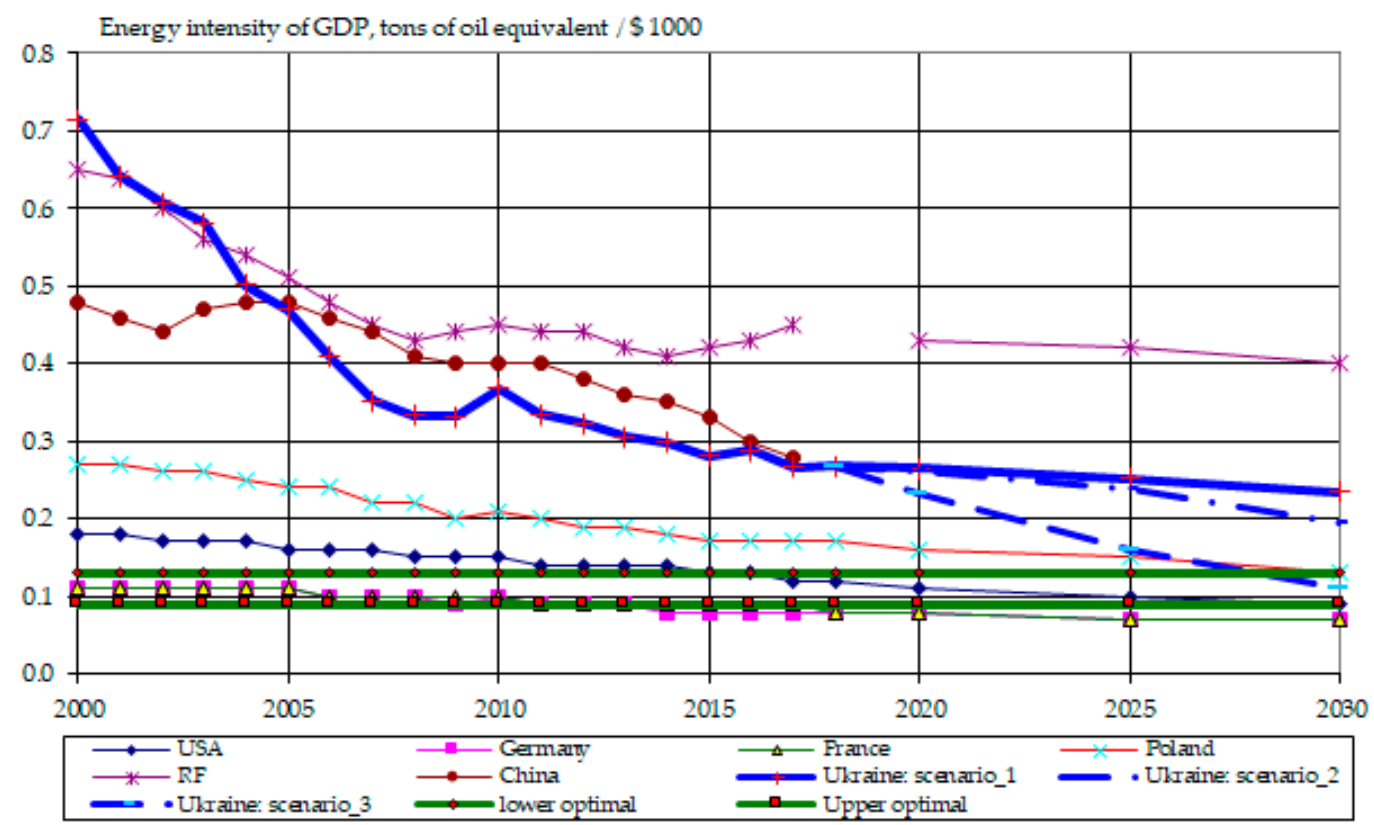

Figure 7. Comparative dynamics of the energy intensity of GDP in Ukraine and in the leading countries of the world.

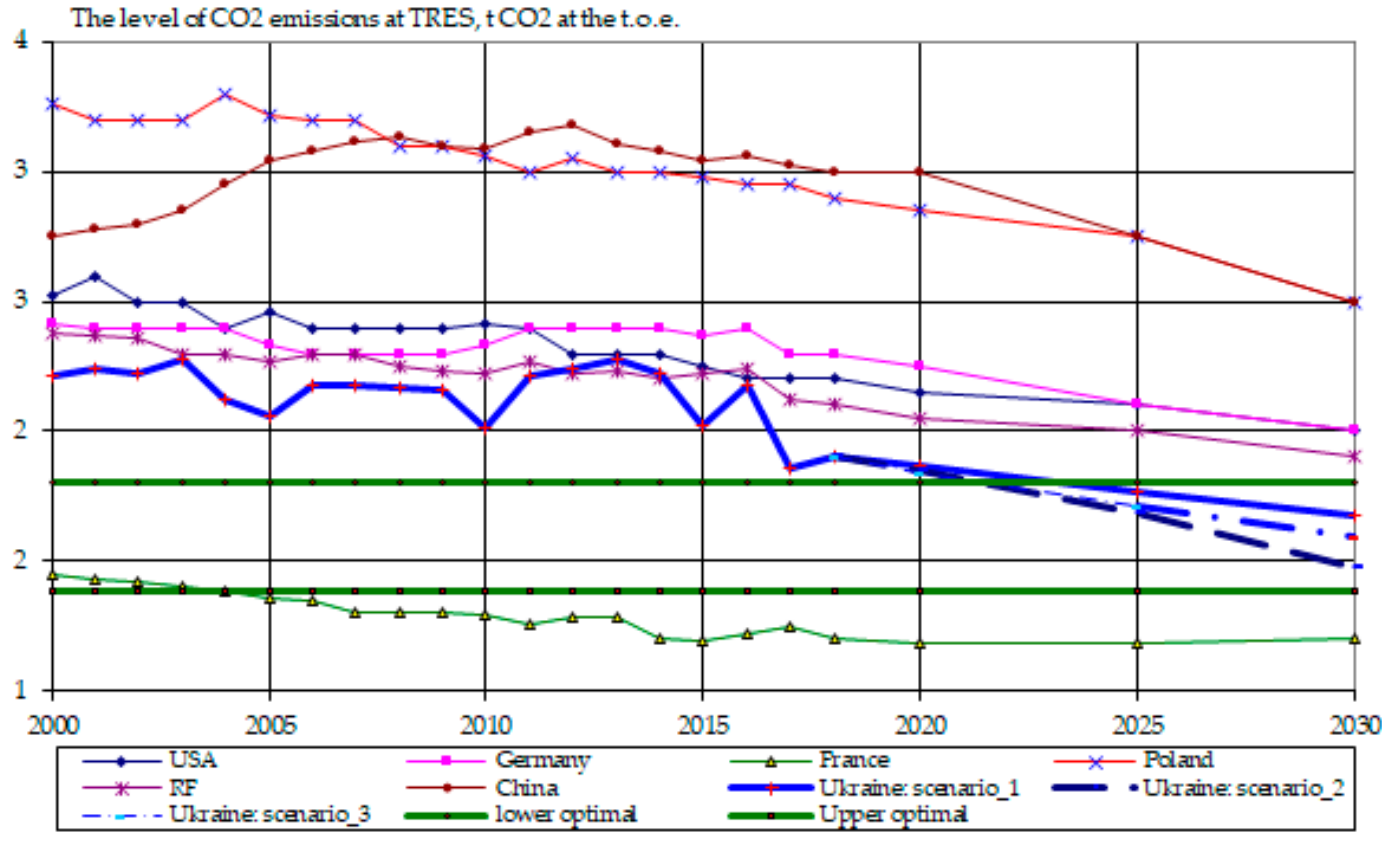

Figure 8. Comparative dynamics of $\mathrm{CO}_{2}$ emissions at TPES in Ukraine and in the leading countries of the world. 


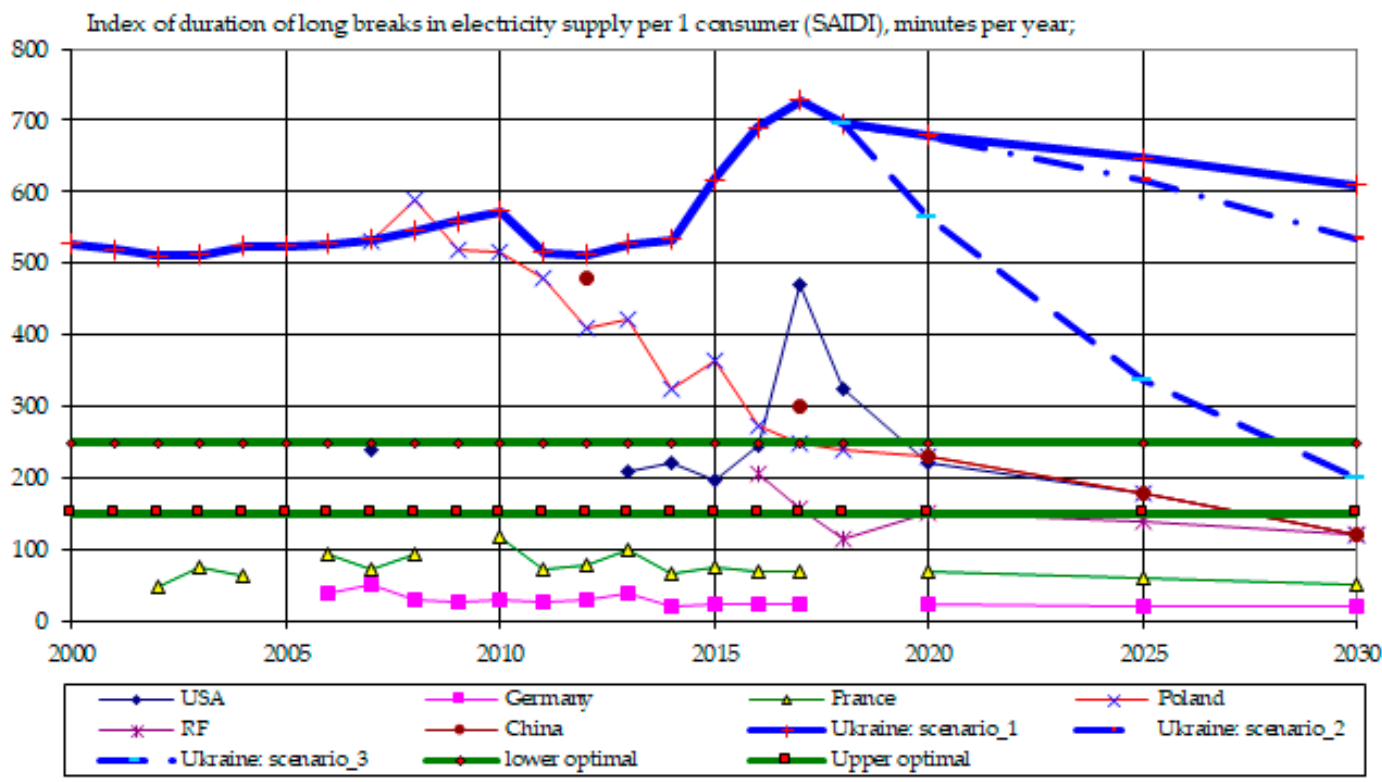

Figure 9. Comparative dynamics of the index of average interruption duration of power supply (SAIDI) in Ukraine and in the leading countries of the world.

For example, a comparative analysis of the calculations of the dynamics of three energy indicators, namely the energy intensity of GDP (Figure 7), the level of $\mathrm{CO}_{2}$ emissions at TPES (Figure 8), and the index of average interruption duration of power supply (SAIDI) (Figure 9), indicates the need for priority action in the direction of reducing the index of the duration of long power outages. At the same time, Ukraine's policy in the field of reducing greenhouse gas emissions provides significant results, which is reflected in the dynamics of such a parameter as the level of $\mathrm{CO}_{2}$ emissions at TPES. In the future, a slight refinement of management influences is needed to achieve the targets. In the direction of improving the energy efficiency of the national economy, some deterioration in the index dynamics is observed, which will require significant adjustment of the country's policy in this area.

The calculated strategic guidelines of the integrated energy security index, components, and their indicators can be considered a scientifically grounded strategic plan for the developing energy security and the country. Monitoring indicators of the actual state of energy security with strategic guidelines of the identified scenarios will allow for objectively defining the current state and trajectory of the country's energy security level and, accordingly, the effectiveness of management policy.

\section{Discussion}

Working out the development strategies for each country in the face of rapid dynamic change, globalization, and open economies is an important and difficult task today. Obviously, the development of strategies is preceded by determining the current situation, and each country decides this for itself. For example, [1] selected twenty-two indicators called "Pakistan Energy Security Indicators" (ESIPs). ESIPs were normalized using the z-estimation method and weighed based on principal component analysis (PCA). In [2], their energy security status was assessed using sets of indicators, indices, and structures, taking into account their dependence on different fuels, their general economic situation, energy pricing policy, access to renewable energy sources, and international relations. The main difficulty is uncertainty, which includes energy security, poor risk management, and a lack of methodological rigor and consistency in developing threshold values for selecting indicators.

The study [3] aims to track the changing definitions of energy security in our time and to formulate a concise and comprehensive definition. In addition, a structured approach identifies and classifies 15 dimensions and related energy security parameters to illustrate 
the range of issues covered by the term and to allow for an accurate assessment of the energy security of energy systems. Having studied 22 OECD countries in the period of 1970 and 2010, [4] concludes that a limited progress has been made by many industrialized countries in ensuring secure, reliable, and affordable energy supplies, as well as in the transition to a low-energy supply, carbon power system.

In [25], by proposing a hybrid model that combines a fuzzy best-worst method and the analysis of data coverage by regions, individual indicators of energy security are examined. The research in [26] tests the hypothesis of the interrelation between 10 energy security indices for 9 indicators of energy shares' profitability. It is shown that the forecasts of profitability obtained by using energy security indices as a predictor are economically significant.

Every year, the World Energy Council (WEC) assesses the state of countries and continents (regions) by means of special indices (energy trilemma index), which are calculated by an international management firm, Oliver Wyman [27]. The balance sheet assessment proposed by the WEC shows how well the country is able to compromise on three competing dimensions: energy security, energy justice (accessibility and affordability), and environmental sustainability. Estimates are calculated by dividing the countries being certified into four groups according to energy efficiency indicators, which are normalized in the range $0-10$. The dossier (profile) of each country is comprised of 13 indicators. Calculation formulas are not published at all-the calculator works in the mode of a cybernetic black box. It is significant that some experts are dissatisfied with the ranking approach to determining the energy trilemma indexes.

The paper [28] is devoted to the definition of the international energy security risk index, which contains information on historical trends and government forecasts to determine policies and other factors that positively or negatively affect international energy security.

However, in the existing publications, there is no established definition of the list of energy security indicators; there is no substantiation of the limits of safe existence-the vector of threshold values of components and indicators, without comparison with which there is no sense in evaluating indicators. Integrated convolution of indicators and their threshold values is not always performed; none of the approaches takes into account dynamic weights. As for strategizing, this is not the case at all.

This study proceeds from the belief in the possibility of building an adequate model of strategizing in the field of energy security. In general, from the point of view of goal setting, various methodological approaches are possible, among which, three main ones are most often used:

- $\quad$ extrapolation of the current state of the system into the future ("the past determines the future") - forming the goals by transferring to the future the current characteristics of the system (organizational, institutional, and functional structure of the relations pattern in energy markets; the current set of technologies; cost of capital; worldviews, etc.), which, oddly enough, is a fairly common practice, although it does not meet the requirements of today;

- $\quad$ selection of target benchmarks (benchmarking) — setting goals with an emphasis on achieving a competitive level with similar systems (selecting the parameter values of the most important characteristics of the system, such as "income level", "energy efficiency of the economy", "market concentration", or "level of investment attractiveness", etc.);

- designing the future of the system - setting goals given the place and role of the system in "larger" systems in the future (for example, the role and place of "energy security" in the system of "national security" or "sustainable development" in the future, taking into account the development trajectory of social, economic, technological, and other aspects of the system (expectations of changes in technology, knowledge, etc.). 
When choosing such a way of strategizing as "designing the future of the system", researchers face two subtasks, namely to design a "smaller" system as an element of a "bigger" one and, at the same time, do so in view of the "future".

The use of a systemic approach to systems' analysis becomes an effective tool for "designing the future of the system" because it allows/demands from the researcher to disclose their research object not only through a set of parameters that reflect its "external" perception, but also through the "internal procedurality" of the system.

The need to analyze the "functions", "processes", and "quality of material" of the system and its individual elements, such as "quality of the management elite" is gaining awareness both in practice and in research. In particular, the Universität St. Gallen in Switzerland is implementing a research project aimed at measuring the quality of elites around the world and compiles the Elite Quality Index [58], which simplifies the researcher's task of designing a future system. This description allows for unifying the process of selecting characteristics important for the functioning of the object, as well as predicting the dynamics of its development, which allows for supplementing the analysis of energy security not only by assessing the current state of parameters but also by forming a development trajectory.

Energy security objectives are defined for all components of the system description of the management object, and relate to the definition of objectives for the level of the group of the "integrated system" parameters, i.e., such parameters that are perceived by an "external" observer, namely: extraction of primary resources, the volume of their exports or imports, the energy efficiency of energy resources' conversion, or the volume of greenhouse gas emissions by energy industries. Objectives are also defined in relation to the internal processes of the system, which are determined through the transformation of institutions and functioning mechanisms of energy and related industries in the new socio-economic, political, and technological conditions.

For example, the change in the electricity market model (from the centralized and regulated model to the liberal and competitive one), which was implemented in Ukraine by adopting relevant legislation in 2019, seemed, to the "external" observer, a very successful step for Ukraine towards improving the energy market's efficiency and attracting investment in the industry. This is how EU experts and politicians perceive Ukraine's progress in implementing the agreements with Ukraine in the field of energy reforming, in particular in implementing the EU-Ukraine Association Agreement.

At the same time, the processes taking place in the domestic energy market of Ukraine indicate the existence of significant problems that threaten the successful implementation of the decision to reform market relations, but also threaten the energy and national security of Ukraine. The problem lies in the need to form new elements and connections in the system (creating operators on different market segments, stock exchanges, market regulators; introducing software to automate calculations, as well as a new market regulation system), changing the "quality" of the system's elements and its material (tasks on education, staff retraining, new training programs, etc.). These decisions have not been fully implemented in market practices and, together with such parameters as "quality of policy" in the energy sector and "compliance of politicians with the challenges facing the system", pose a threat of discrediting reforms, furthering technical degradation of energy infrastructure, and increasing the cost of energy supply for the population.

Thus, the systemic approach is, in fact, a methodological tool for identifying areas, aspects, and problems of energy security that should be taken into account when strategizing the achievement of these goals. The proposed systemic approach to evaluating the level of energy security and strategizing allows this to be done, including through the introduction of individual indicators that reflect these aspects.

When designing the "future" of the system, the researcher can rely on the complex of knowledge accumulated in such a scientific discipline as foresighting, which is defined as the systematic on-going attempts to foresee the longer-term future of science, technology, the economy and society aiming to stipulate the domains of strategic research and the 
rise of comprehensive technologies presumably bringing significant economic and social gains [59] (p. 96).

Usually, foresighting as a technology incorporates methods developed in various scientific fields and is aimed at predicting the desired, not any, future. Such methods include, for example: the Delphi method, identification of critical technologies, scenario development, expert panels, SWOT analysis, economic and mathematical modeling, brainstorming, regression analysis, extrapolation, simulation modeling, multicriteria analysis, etc. Unfortunately, most of the methods used are based on expert estimates, which certainly reduces the scientific and practical value of the results [60-62]. Another group of methods, which is based on the principles of classical forecasting - "the past determines the future", is also unsuitable for constructing the desired future, because the future acquires other forms and structures, as a result of which, the role of prehistory is significantly reduced.

Thus, the definition of long-term factors and trends comes to the foreground during foresighting, rather than building long-term forecasts for the development of the national economy. Therefore, in foresighting, in contrast to forecasting, the emphasis is made on qualitative rather than quantitative results.

Therefore, the methodological basis for strategizing the sustainable development of economic systems (including energy) is the concept of sustainable development [29], (pp. 24-46), which contains the stages of identification in the security dimension through integrated assessment and strategizing on the assumption "the future is stipulated by the trajectory into the future" by means of applying adaptive control methods from the management theory.

According to calculations, the level of energy security for all the years of independent Ukraine's existence has always been in the critical (red) zone-below the lower threshold.

At the same time, the gradual improvement of the integral index, "the integral system", should be noted (Figure 4a). In general, this dynamic indicates Ukraine's progress in eliminating the impact of the most threatening factors on energy security, in particular, it is about reducing Ukraine's dependence on energy supplies from a single monopoly source (Russia) (stopping natural gas imports from Russia and regulating gas supplies from the $\mathrm{EU}$, the reduction of up to $50 \%$ of the volume of nuclear fuel supplies of the Russian company TVEL, due to cooperation with Westinghouse); overall reduction of needs in importing energy resources, especially coal; and significant reduction of greenhouse gas emissions. This is how the dynamics of Ukraine can be perceived from the point of view of an "external" observer who evaluates the state of energy security through a set of selected and most common indicators that are taken into account by most researchers in the field of energy security.

At the same time, although the dynamics of the integral index "elements and links" (Figure $4 \mathrm{~b}$ ) reflect the relative consistency of Ukraine's policy in transforming the structure of the energy sector, the introduction of new models of energy market regulation (adoption of legislation, creation of new institutions, mechanisms for regulators and market participants), and the dynamics of the integrated index "functions and roles" (Figure 4c), which reflects the incompleteness of this process and the availability of serious problems in real transformations due to the persistence of non-transparency of management decisions, the preservation of certain interest groups' influence on management decisions, the continuation of populist government policies, and cross-subsidization in the market.

At the same time, the "internal" observer may note that the improvement of certain parameters was not due to the successful implementation of management decisions in this area, but rather due to economic decline. Moreover, the dynamics of the integrated index "Processes" (Figure 4d) shows the existence of significant instability in the process of transformation, and even a sharp deterioration after 2014. The most critical situation affecting efforts to increase energy security is in the management sphere.

A systemic approach to analyzing management processes and the transformation of the management decision-making system in the energy sector (evaluating the functional purpose of system elements and actual information and resource flows in the system) 
allowed for identifying the process of "rental exploitation" of energy by informal influence groups, which is reflected in the progressive depreciation of fixed assets of the energy sector of Ukraine, the accumulation of debt obligations, and the reduction of personnel qualification at economic entities and governing bodies. In fact, "depreciation of fixed assets of state-owned enterprises", "growth of the private assets' share", and "growth of debt for supplied energy/resources" are indicators that reflect the process of withdrawal of resources from energy assets. In the presence of such a process of "rent exploitation", the provision of government support to economic entities (government spending on modernization, lending, subsidies to reduce production costs, debt repayment, etc.) is an inadequate management decision that will only worsen the state of energy security.

Dynamics of the integrated index "the system's material" (Figure 4d) reflects a significant decline in both the technical reliability of Ukraine's power engineering and a sharp decline in the quality of public policy and the qualifications of management. Therefore, it is the internal system processes and the quality of the material (in particular the quality of the management system) that, in the near future, may level Ukraine's achievements in improving energy security. The calculations reflect the following conclusions, which are displayed in the list of the most critical threats to the country's energy security (Table 4).

Another example of the need to estimate the "external" and "internal" parameters of energy security is the development of renewable energy. In general, the parameter of energy security estimates, such as the "share of renewable energy" in the country's overall energy balance, is one of the most important, especially according to the "external" observers from the EU. In previous years, Ukraine has adopted legislation that stimulates the development of solar and wind energy, which has increased the installed capacity of solar and wind power plants from 2117.3 MW at the end of 2018 to $8516 \mathrm{MW}$ at the beginning of 2021 [48]. At the same time, the sharp increase in renewable generation occurred without compensatory measures to increase the flexibility of the power system (in Ukraine there is a lack of powerful energy storage systems and shunting capacity), which only leads to a deterioration in the system's operational security.

The lack of appropriate changes in the system of interrelations among the elements and the non-introduction of new functions and the links among them only destroy the "old" process of forecasting supply and demand in the electricity market. In turn, this leads to problems of balancing the system and the introduction of forced restrictions on the planned work of market participants. An additional burden is the requirement to pay a high "green tariff" for all volumes of RES energy not accepted by the system due to operational security requirements. All this is reflected in the growth of the index of average interruption duration of power supply (SAIDI) (Table 4 shows the criticality of this threat), the cost of energy supply to consumers (through the introduction of incentives, the highest in Europe) and, as a result, the termination of calculations for "excessive" amounts of generated green energy (due to the gradual reduction of consumption and financial resources of the market).

Therefore, an "external" observer making judgments about the energy security of a country (for example, Ukraine) on the basis of international databases that reflect a comprehensive approach to energy security evaluation, may draw an erroneous conclusion. At the same time, the systemic approach allows for focusing on the processes occurring within the system, the quality of the system material, and obtaining a more adequate evaluation of the state of affairs, as well as determining the strategic goals.

The dynamics of integrated indices in comparison with integrated threshold values is clear evidence of the policy effectiveness in this area. The task of the policy is to translate the integrated index first into the crisis (orange) zone-between the lower threshold and the lower optimal, and then into the optimal (green) zone of sustainable development through introducing appropriate measures.

Thus, the comparison of integral indices with integral threshold values translates the concept of "development" into the concept of "security". Moreover, the developed method of evaluating the level and strategizing energy security will become instrumental 
in shaping the goals of the country's energy policy, as it will justify strategic decisions in the field of power engineering based on the quantitative evaluation of their impact on national security and the country's sustainable development.

Thus, the dynamics of integrated indices in comparison with integrated threshold values is clear evidence of the policy effectiveness in this area. The task of the policy is to translate the integrated index first into the crisis (orange) zone-between the lower threshold and the lower optimal, and then into the optimal (green) zone of sustainable development through the introduction of appropriate measures.

Thus, the comparison of integral indices with integral threshold values translates the concept of "development" into the concept of "security". Moreover, the developed method of estimating the level and strategy of energy security becomes instrumental in shaping the goals of energy policy, as it will justify strategic decisions in the field of energy based on quantitative assessment of their impact on the country's national security and sustainable development. The application of a systemic approach, together with estimating long-term perspectives of science, technology, economy and society, strategic directions of research, and new technologies (of classical foresighting), with the methodology of identification in the security dimension and strategizing based on the principle "the future is determined by the future trajectory" eliminates existing shortcomings and provides new opportunities not only for the definition of long-term factors and trends, but also for the scientific construction of the desired future - that is, the creation of a tool for scientific and strategic foresighting.

\section{Conclusions}

This paper reveals the methods of integrating energy security into the structural and functional scheme of national security of Ukraine, which determines the place and role of energy security in ensuring fundamental national interests-sustainable development of the national economy, civil society, and the government in order to increase the level and quality of life of the population, as well as state sovereignty and independence, Ukraine's integration into the European energy space, etc.

A new model of energy security description is proposed based on the application of a systemic approach and the ability to operate with system dynamics. This presentation allows for harmonizing existing approaches to evaluating the level of energy security, in particular, evaluating security as a state of protectability and the capability of the system to adapt to new challenges.

To solve the problems of energy security, a universal methodology of identifying and strategizing in the field of national security is applied, which allows for comparing indicators of different security areas and substantiating strategic scenarios of security development. The basis of the methodology is the concept of sustainable development from the standpoint of security, which provides for the definition of safe living boundaries (vector of threshold values) and justification of the criterion of sustainable development as the average value of the "homeostatic plateau".

An integrated multifactor model of energy security in the context of sustainable development has been developed. The modeling of the energy security level for identifying the existing level of security both for individual components and for energy security in general was carried out. The list of the most important threats by distance from the criterion of sustainable development is determined and the significance of their impact on the overall level of energy security is calculated for developing appropriate institutional measures to respond to the identified threats.

Considering the principle of classical forecasting "the past determines the future" as unacceptable for strategizing, a new approach to strategic planning is applied, based on the principle: "the future is determined by the trajectory into the future", and consists, first, of determining what distance from the criterion of sustainable development (the average value of the "homeostatic plateau") an integrated index of energy security is located, setting the trajectory of achieving the desired goals (strategic scenarios) and solving the problem 
to synthesize the required values of components and indicators using adaptive control methods of management theory by solving the inverse problem that provides the desired trajectory of energy security in the context of sustainable development.

Thus, the approach proposed by the authors to ensure energy security allows for combining at the system level a systemic approach, strategizing and goal setting, analysis of threats and risks to achieve strategic goals (risk-oriented approach), strategic planning, and determining the list of indicators, achieving the target state in a quantity sufficient for adequate evaluation.

The proposed approach for developing strategic scenarios of sustainable development from the point of view of security is universal, and can be applied to certain areas of national security for any country, economic district, region, or type of activity in strategic planning for medium- and long-term prospects.

The proposed methodological approach has practical significance for the scientific and expert community, as well as for politicians and managers at various levels. This approach allows for unifying the process of estimating the level of security for research objects of different levels (national or sectoral level, a separate energy supply system, or an enterprise).

The implementation of a systemic approach to analyzing the situation will remove the obvious contradiction of "external" and "internal" understanding of the situation in various areas of government. This will allow for better communication and mutual understanding among all stakeholders in the field of energy security. Ukraine and the EU will be able to better understand the problems of national (Ukraine), internal (the EU), and regional energy security (the EU and Eastern Partnership countries) and agree on priorities for action.

The proposed study is of practical importance for improving the national system of strategic planning. The proposed approach can be used as a basis for the Energy Security Strategy of Ukraine, which should be approved in the near future in the country. The developed methodology for strategizing and estimating the level of energy security can be implemented in the system of public administration in the form of methods for estimating the level of energy security. This study allows for creating a coherent system for defining strategic goals, identifying threats, identifying priority management decisions, and monitoring the approximation of the system of the goals set. Such a system can become a universal tool to be used in various countries for systems of various levels.

Author Contributions: Conceptualization, Y.K., A.K., O.S., H.D., D.B., and J.K.; methodology, Y.K., A.K., O.S., H.D., D.B., and J.K.; software, Y.K., A.K., O.S., H.D., D.B., and J.K.; validation, Y.K., A.K., O.S., H.D., D.B., and J.K.; formal analysis, YY.K., A.K., O.S., H.D., D.B., and J.K.; investigation, Y.K., A.K., O.S., H.D., D.B., and J.K.; resources, Y.K., A.K., O.S., H.D., D.B., and J.K.; data curation, Y.K., A.K., O.S., H.D., D.B., and J.K.; writing-original draft preparation, Y.K., A.K., O.S., H.D., D.B., and J.K.; writing-review and editing, Y.K., A.K., O.S., H.D., D.B., and J.K.; visualization, Y.K., A.K., O.S., H.D., D.B., and J.K.; supervision, Y.K., A.K., O.S., H.D., D.B., and J.K.; project administration, Y.K., A.K., O.S., H.D., D.B., and J.K.; funding acquisition, Y.K., A.K., O.S., H.D., D.B., and J.K. All authors have read and agreed to the published version of the manuscript.

Funding: This research received no external funding.

Acknowledgments: The authors are very grateful to the anonymous referees for their helpful comments and constructive suggestions.

Conflicts of Interest: The authors declare no conflict of interest. 


\section{References}

1. Bin Abdullah, F.; Iqbal, R.; Hyder, S.I.; Jawaid, M. Energy security indicators for Pakistan: An integrated approach. Renew. Sustain. Energy Rev. 2020, 133, 110122. [CrossRef]

2. Axon, C.; Darton, R. Sustainability and risk-A review of energy security. Sustain. Prod. Consum. 2021, 27, 1195-1204. [CrossRef]

3. Azzuni, A.; Breyer, C. Definitions and dimensions of energy security: A literature review. Wiley Interdiscip. Rev. Energy Environ. 2017, 7, e268. [CrossRef]

4. Brown, M.A.; Wang, Y.; Sovacool, B.K.; D'Agostino, A.L. Forty years of energy security trends: A comparative assessment of 22 industrialized countries. Energy Res. Soc. Sci. 2014, 4, 64-77. [CrossRef]

5. Cherp, A.; Adenikinju, A.; Goldthau, A.; Hernandez, F.; Hughes, L.; Jansen, J.; Jewell, J.; Olshanskaya, M.; de Oliveira, R.S.; Sovacool, B.; et al. Chapter 5-Energy and Security. In Global Energy Assessment_Toward a Sustainable Future; Davidson, O., Ed.; Cambridge University Press: Cambridge, UK, 2012; pp. 325-384.

6. Chester, L. Conceptualising energy security and making explicit its polysemic nature. Energy Policy 2010, 38, 887-895. [CrossRef]

7. Dźwigoł, H.; Dźwigoł-Barosz, M.; Zhyvko, Z.; Miśkiewicz, R.; Pushak, H. Evaluation of the energy security as a component of national security of the country. J. Secur. Sustain. Issues 2019, 8, 307-317. [CrossRef]

8. Gong, X.; Wang, Y.; Lin, B. Assessing dynamic China's energy security: Based on functional data analysis. Energy 2021, 217, 119324. [CrossRef]

9. Kruyt, B.; Van Vuuren, D.; De Vries, H.; Groenenberg, H. Indicators for energy security. Energy Policy 2009, 37, $2166-2181$. [CrossRef]

10. Lyulyov, O.; Pimonenko, T.; Kwilinski, A.; Dzwigol, H.; Dzwigol-Barosz, M.; Pavlyk, V.; Barosz, P. The Impact of the Government Policy on the Energy Efficient Gap: The Evidence from Ukraine. Energies 2021, 14, 373. [CrossRef]

11. Mazurkiewicz, J.; Lis, P. Diversification of energy poverty in Central and Eastern European countries. Virtual Econ. 2018, 1, 26-41. [CrossRef]

12. Miskiewicz, R. The importance of knowledge transfer on the energy market. Polityka Energetyczna Energy Policy J. 2018, 21, 49-62. [CrossRef]

13. Pająk, K.; Kvilinskyi, O.; Fasiecka, O.; Miskiewicz, R. Energy Security in Regional Policy in Wielkopolska Region of Poland. Econ. Environ. 2017, 2, 122-138.

14. Phoumin, H.; Kimura, F.; Arima, J. ASEAN's Energy Transition towards Cleaner Energy System: Energy Modelling Scenarios and Policy Implications. Sustainability 2021, 13, 2819. [CrossRef]

15. Sovacool, B.K.; Brown, M.A. Competing Dimensions of Energy Security: An International Perspective. Annu. Rev. Environ. Resour. 2010, 35, 77-108. [CrossRef]

16. Sovacool, B.K.; Mukherjee, I. Conceptualizing and measuring energy security: A synthesized approach. Energy 2011, 36, 5343-5355. [CrossRef]

17. Winzer, C. Conceptualizing energy security. Energy Policy 2012, 46, 36-48. [CrossRef]

18. Asia Pacific Energy Research Centre (APERC). A Quest for Energy Security in the 21st Century: Resources and Constraints; Institute of Energy Economics: Tokyo, Japan, 2007; pp. 1-113. Available online: https://aperc.or.jp/file/2010/9/26/APERC_2007_A_Quest_ for_Energy_Security.pdf (accessed on 12 January 2021).

19. International Energy Agency (IEA). Defining Energy Security. Available online: https://www.iea.org/ (accessed on 12 January 2021).

20. Cherp, A.; Jewell, J. Energy Security Assessment Framework and Three Case-Studies. In International Energy Security Handbook; Dryer, H., Trombetta, M.J., Eds.; Edward Elgar Publishing: Cheltenham, UK, 2013; pp. 146-173.

21. Cherp, A.; Jewell, J. The concept of energy security: Beyond the four As. Energy Policy 2014, 75, 415-421. [CrossRef]

22. Sukhodolia, O. Problems of Defining the Scope of Energy Security Regulation. Strateg. Panor. 2019, 1, 5-17.

23. Sukhodolia, O. The Energy Dimension of War. An Overview of the Ukrainian Events in 2014-2016. Energy Secur. 2017, 11, 25-34.

24. Sukhodolia, O. Energy Security: Assessment, Goal Setting, Threats. Sci. J. Acad. Natl. Secur. 2019, 3, 30-63.

25. Huang, B.; Zhang, L.; Ma, L.; Bai, W.; Ren, J. Multi-Criteria Decision Analysis of China's Energy Security from 2008 to 2017 based on Fuzzy BWM-DEA-AR model and Malmquist Productivity Index. Energy 2021, 120481, 120481. [CrossRef]

26. Iyke, B.N.; Tran, V.T.; Narayan, P.K. Can energy security predict energy stock returns? Energy Econ. 2021, 94, 105052. [CrossRef]

27. Energy Trilemma Index. Available online: https://trilemma.worldenergy.org (accessed on 1 April 2021).

28. International Energy Security Risk Index. Available online: https://www.globalenergyinstitute.org/international-energysecurity-risk-index (accessed on 1 April 2021).

29. Kharazishvili, Y.M. Systemic Security of Sustainable Development: Assessment Tools, Reserves and Strategic Implementation Scenarios. Monograph; Institute of Industrial Economics of the National Academy of Sciences of Ukraine: Kyiv, Ukraine, 2019.

30. Dalevska, N.; Khobta, V.; Kwilinski, A.; Kravchenko, S. A model for estimating social and economic indicators of sustainable development. Entrep. Sustain. Issues 2019, 6, 1839-1860. [CrossRef]

31. Kharazishvili, Y.; Kwilinski, A.; Grishnova, O.; Dzwigol, H. Social Safety of Society for Developing Countries to Meet Sustainable Development Standards: Indicators, Level, Strategic Benchmarks (with Calculations Based on the Case Study of Ukraine). Sustainability 2020, 12, 8953. [CrossRef]

32. Kuzior, A.; Kwilinski, A.; Tkachenko, V. Sustainable development of organizations based on the combinatorial model of artificial intelligence. Entrep. Sustain. Issues 2019, 7, 1353-1376. [CrossRef] 
33. Hazell, E. Disaggregating Ecosystem Benefits: An Integrated Environmental-Deprivation Index. Sustainability 2020, $12,7589$. [CrossRef]

34. Petrova, T.; Grunin, A.; Shakhbazyan, A. Integral Index of Traffic Planning: Case-Study of Moscow City's Transportation System. Sustainability 2020, 12, 7395. [CrossRef]

35. Pamučar, D.; Stević, Ž.; Sremac, S. A New Model for Determining Weight Coefficients of Criteria in MCDM Models: Full Consistency Method (FUCOM). Symmetry 2018, 10, 393. [CrossRef]

36. Migilinskas, D.; Ustinovichius, L. Normalisation in the selection of construction alternatives. Int. J. Manag. Decis. Mak. 2007, 8, 623. [CrossRef]

37. Kwilinski, A.; Tkachenko, V.; Kuzior, A. Transparent Cognitive Technologies to Ensure Sustainable Society Development. J. Secur. Sustain. Issues 2019, 9, 561-570. [CrossRef]

38. Lyeonov, S.; Pimonenko, T.; Bilan, Y.; Štreimikienè, D.; Mentel, G. Assessment of Green Investments' Impact on Sustainable Development: Linking Gross Domestic Product Per Capita, Greenhouse Gas Emissions and Renewable Energy. Energies 2019, 12, 3891. [CrossRef]

39. Kharazishvili, Y.; Grishnova, O.; Kamińska, B. Standards of living in Ukraine, Georgia, and Poland: Identification and strategic planning. Virtual Econ. 2019, 2, 7-36. [CrossRef]

40. Kuzior, A.; Kuzior, P. The Quadruple Helix Model as a Smart City Design Principle. Virtual Econ. 2020, 3, 39-57. [CrossRef]

41. Kuzior, A.; Lobanova, A. Tools of Information and Communication Technologies in Ecological Marketing under Conditions of Sustainable Development in Industrial Regions (Through Examples of Poland and Ukraine). J. Risk Financ. Manag. 2020, 13, 238. [CrossRef]

42. Czyżewski, B.; Matuszczak, A.; Polcyn, J.; Smędzik-Ambroży, K.; Staniszewski, J. Deadweight loss in environmental policy: The case of the European Union member states. J. Clean. Prod. 2020, 260, 121064. [CrossRef]

43. Czyzewski, B.; Matuszczak, A.; Miśkiewicz, R. Public Goods Versus the Farm Price-Cost Squeeze: Shaping the Sustainability of the Eu's Common Agricultural Policy. Technol. Econ. Dev. Econ. 2019, 25, 82-101. [CrossRef]

44. Miśkiewicz, R. Efficiency of Electricity Production Technology from Post-Process Gas Heat: Ecological, Economic and Social Benefits. Energies 2020, 13, 6106. [CrossRef]

45. Miśkiewicz, R. The Impact of Innovation and Information Technology on Greenhouse Gas Emissions: A Case of the Visegrád Countries. J. Risk Financ. Manag. 2021, 14, 59. [CrossRef]

46. Lyulyov, O.; Pimonenko, T.; Stoyanets, N.; Letunovska, N. Sustainable Development of Agricultural Sector: Democratic Profile Impact Among Developing Countries. Res. World Econ. 2019, 10, 97. [CrossRef]

47. Sukhodolya, O.; Kharazishvili, Y.; Bobro, D. Energy Security of Ukraine: Methodology of System Analysis and Strategic Planning; NISS: Kyiv, Ukraine, 2020.

48. State Statistics Service of Ukraine. Available online: http:/ / www.ukrstat.gov.ua/ (accessed on 12 January 2021).

49. Sukhorukov, A.I.; Kharazishvili, Y.M. Modeling and Forecasting of Socio-Economic Development of Regions of Ukraine: Monograph; NISS: Kyiv, Ukraine, 2012.

50. Kharazishvili, Y.M. Light and Shadow of the Economy of Ukraine: Reserves of Growth and Modernization. Econ. Ukr. 2017, 4, $22-45$.

51. International Energy Agency (IEA). Available online: https:/ /www.iea.org/data-and-statistics?country=WORLD\&fuel=Energy \% 20supply\&indicator=CoalProdByType (accessed on 12 January 2021).

52. The World Bank. Available online: https://data.worldbank.org/indicator (accessed on 12 January 2021).

53. Eurostat. Eurostat Database. Available online: https:/ / ec.europa.eu/eurostat/data/database (accessed on 1 September 2020).

54. Van Gigch, J.P. Applied General Systems Theory, 2nd ed.; Harper and Row: New York, NY, USA, 1978.

55. Sukhodolia, O.; National Institute for Strategic Studies; Kharazishvili, Y.; Bobro, D. Methodological Basis for Asessing the Level and Strategic Planing of the Energy Security of Ukraine. Econ. Ukr. 2020, 2020, 20-42. [CrossRef]

56. Turner, J.C. Modern Applied Mathematics: Probability, Statistics, Operational Research; Van Nostrand Reinhold: New York, NY, USA, 1972.

57. International Monetary Fund. Available online: https://www.imf.org/en/Home (accessed on 12 January 2021).

58. Elite Quality Index. Available online: https:/ / elitequality.org/ (accessed on 12 January 2021).

59. Cuhls, K. From forecasting to foresight processes?new participative foresight activities in Germany. J. Forecast. 2003, $22,93-111$. [CrossRef]

60. Dzwigol, H. Methodological and empirical platform of triangulation in strategic management. Acad. Strateg. Manag. J. 2020, 19, $1-8$.

61. Dźwigoł, H.; Dźwigoł-Barosz, M. Scientific Research Methodology in Management Sciences. Financ. Crédit. Act. Probl. Theory Pract. 2018, 2, 424-437. [CrossRef]

62. Dzwigol, H. Meta-Analysis in Management and Quality Sciences. Mark. Manag. Innov. 2021, 1, 324-335. [CrossRef] 